OPEN ACCESS

Edited by:

Karina Silina,

University of Zurich, Switzerland

Reviewed by:

Marie-Caroline Dieu-Nosjean, Institut National de la Santé et de la

Recherche Médicale, France

Mohey Eldin El Shikh,

Queen Mary University of London,

United Kingdom

Kai-Michael Toellner,

University of Birmingham,

United Kingdom

*Correspondence:

Reza Motallebzadeh

r.motallebzadeh@ucl.ac.uk

Specialty section:

This article was submitted

to Cancer Immunity and

Immunotherapy,

a section of the journal

Frontiers in Immunology

Received: 23 September 2017 Accepted: 09 November 2017 Published: 23 November 2017

Citation:

Alsughayyir J, Pettigrew GJ and Motallebzadeh R (2017) Spoiling

for a Fight: B Lymphocytes As Initiator and Effector Populations within Tertiary Lymphoid Organs in Autoimmunity and Transplantation.

Front. Immunol. 8:1639. doi: 10.3389/fimmu.2017.01639

\section{Spoiling for a Fight: B Lymphocytes As Initiator and Effector Populations within Tertiary Lymphoid Organs in Autoimmunity and Transplantation}

\author{
Jawaher Alsughayyir ${ }^{1}$, Gavin J. Pettigrew ${ }^{1}$ and Reza Motallebzadeh ${ }^{2,3,4 *}$ \\ ${ }^{1}$ School of Clinical Medicine, University of Cambridge, Cambridge, United Kingdom, ${ }^{2}$ Division of Surgery and Interventional \\ Science, University College London, London, United Kingdom, ${ }^{3}$ Institute of Immunity and Transplantation, University College \\ London, London, United Kingdom, ${ }^{4}$ Department of Nephrology, Urology and Transplantation, Royal Free Hospital, London, \\ United Kingdom
}

Tertiary lymphoid organs (TLOs) develop at ectopic sites within chronically inflamed tissues, such as in autoimmunity and rejecting organ allografts. TLOs differ structurally from canonical secondary lymphoid organs (SLOs), in that they lack a mantle zone and are not encapsulated, suggesting that they may provide unique immune function. A notable feature of TLOs is the frequent presence of structures typical of germinal centers (GCs). However, little is known about the role of such GCs, and in particular, it is not clear if the B cell response within is autonomous, or whether it synergizes with concurrent responses in SLOs. This review will discuss ectopic lymphoneogenesis and the role of the B cell in TLO formation and subsequent effector output in the context of autoimmunity and transplantation, with particular focus on the contribution of ectopic GCs to affinity maturation in humoral immune responses and to the potential breakdown of self-tolerance and development of humoral autoimmunity.

Keywords: B cells, tertiary lymphoid organs, autoimmunity, transplantation, germinal center

\section{INTRODUCTION}

Adaptive immune responses are generally initiated within canonical secondary lymphoid organs (SLOs), such as lymph nodes (LN) and the spleen. SLOs are specially organized to facilitate presentation of antigen to the very small number of responder clones within the total lymphocyte population (1). Over the last few years, it has become increasingly evident that tertiary lymphoid organs (TLOs), also known as ectopic lymphoid tissue, can develop within peripheral organs in response to alloimmunity, chronic inflammation, cancer, chronic infection, and autoimmunity (2-6). Although TLOs have been described that contain predominantly a T cell infiltrate, a B cell component is generally also present, and often appears to dominate. This raises two fundamental questions: what role do B cells play in the genesis of TLOs; and what is their effector function once that TLO is established? The latter is particularly interesting, because although immunohistological evidence of complex germinal center (GC) activity is often detectable, a number of recent, seminal papers have reinforced the complexities of the GC reaction. The GC reaction is geared to producing high-affinity long-lived plasma cells (LLPCs) and memory B cells, but this requires precise spatiotemporal control of the key cellular interactions within the follicle. Here, we consider the role of the B cell, not only as a potential initiator in the formation of TLOs (in the context of solid-organ transplantation and autoimmunity) but also as a critical determinant of its output. 


\section{INDUCTION AND FORMATION OF TLOs-THE PLAYERS}

\section{The Initiators-B Cells or Not B Cells?}

The initiation of lymphoid organogenesis requires the presence of hematopoietic $\mathrm{CD}^{+} \mathrm{CD}^{-}{ }^{-\mathrm{RANK}}{ }^{+} \mathrm{IL}-7 \mathrm{R} \alpha^{\mathrm{hi}}$ lymphoid tissue inducer (LTi) cells [known also as type 3 innate lymphoid cells (7-9)]. These express retinoic acid-related orphan receptor- $\gamma t$ (ROR- $\gamma \mathrm{t}$ ) and lymphotoxin $\mathrm{LT} \alpha_{1} \beta_{2}$; a heterotrimeric complex that comprises membrane-bound LT $\beta$ and soluble LT $\alpha$; its binding to lymphotoxin- $\beta$ receptor (LT $\beta \mathrm{R}$ ) on VCAM- $1^{+}$ICAM- $1^{+}$ $\mathrm{LT} \mathrm{R}^{+}$stromal tissue organizer (LTo) cells establishes a lymphoid chemokine feedback loop, involving CC-chemokine ligand 19 (CCL19), CCL21, and CXC-chemokine ligand 13 (CXCL13), which in turn drives early B/T cell clustering and segregation as well as the differentiation of high endothelial venules (HEVs) (10-14). Although the organogenesis of the spleen, LNs, and Peyer's patches clearly requires LTi cells $(11,15,16)$, there remains uncertainty about the identity of the equivalent cells that prompt TLO induction.

$\mathrm{CD}^{+} \mathrm{CD}^{-}$LTi cells are present in adults, albeit at much lower frequency $(17,18)$, express lymphotoxin (LT) and tumor necrosis factor (TNF) (19) and provide support to T follicular helper $\left(\mathrm{T}_{\mathrm{FH}}\right)$ cells in GCs (20), as well as contributing to memory humoral immune responses (21). Unlike embryonic LTi cells, adult $\mathrm{CD}^{+} \mathrm{CD}^{-}$cells express high levels of OX40L and CD30L (22). LTi cells may be similarly involved in TLO formation (23) but there is conflicting evidence to support this hypothesis. First, interleukin-7 (a key survival factor for LTi cells in developing SLOs) transgenic mice develop organized TLOs after immunization with antigen, in a process that is dependent upon $\mathrm{LT}_{1} \beta_{2}$ and the LTi-associated transcription factor retinoic acid-related orphan receptor- $\gamma \mathrm{t}(\mathrm{ROR}-\gamma \mathrm{t})$ (24). Second, intra-dermal injection of newborn mesenteric LN-derived cells (containing stromal organizer cells and LTi cells but not mature lymphocytes) into adult mice can induce formation of lymphoid tissue in the skin, with the aggregates composed of donor-origin stromal cells and recipient-derived lymphocytes organized into distinctive areas (25). And third, overexpression of CXCL13 in non-lymphoid tissue, such as the pancreas results in TLOs containing B and T cell zones, HEVs, and stromal cells (26); pancreatic tissue in these transgenic animals contain a significant population of CD $4^{+} \mathrm{CD} 3^{-} \mathrm{IL}-7 \mathrm{R} \alpha^{\text {hi }}$ cells, suggesting that chemokine driven LTi-type cells expressing $L T \alpha_{1} \beta_{2}$ (27) may play a role in the formation of ectopic lymphoid tissue as well as native SLOs (26-28). Nevertheless in transgenic models of TLO formation, ectopic lymphoid neogenesis has started before birth and it is possible that de novo TLOs established as a result of chronic inflammation are different to developmentally programmed TLOs in their requirement for LTi cells.

There is, however, also evidence that TLOs can form in the complete absence of LTi cells. For instance, mice deficient in the nuclear hormone ROR- $\gamma \mathrm{t}$ and the transcriptional repressor Id 2 still can still form intestinal TLOs in response to microbiota, despite lacking LTi cells (29). Similarly, Marinkovic et al. showed that formation of TLOs in thyroid tissue occurs by mature CD $3^{+}$
$\mathrm{CD}^{+} \mathrm{T}$ cells, and not by LTi cells, and that these cells promote ectopic HEV development by LT $\beta$ R signaling (30).

One of the main questions, therefore, is what cell type(s), equivalent to LTi and LTo cells for SLO development, drive(s) TLO formation (Figure 1). Since TLOs arise postnatally in response to inflammatory triggers, immune cells may substitute for LTi cells and act as the primary initiators of tertiary lymphoid neogenesis. Analysis of explanted allografts due to chronic rejection has shown that the development of TLOs depends upon the recapitulation of the genetic programme fundamental to the development of SLOs (31). When the reprogramming is incomplete, only naïe $\mathrm{B}$ cell clusters form, whereas if the recapitulation is complete, functional ectopic GCs generating anti-HLA secreting plasma cells develop. This implies that the mechanistic pathways involved in SLO and TLO formation are very similar; as confirmation, we have also shown that LT signaling is essential to the formation of TLOs in chronically rejecting allografts (32). The suggestion that persistent antigen exposure is critical for maintaining TLO organization is supported by the finding of secondary B cell follicles with GCs and only rare primary B cell follicles in chronically inflamed tissues (in autoimmune disease), and by the finding that ectopic (autoimmune) GCs generate plasma cells that produce antibodies specific for antigens that are expressed in the target tissue $(33,34)$.

Lymphotoxin expressing cells other than LTi cells can drive TLO formation, such as M1-polarized pro-inflammatory macrophages (35), and $\mathrm{T}$ (36) and B cells (29) which upregulate LT $\alpha_{1} \beta_{2}$ expression in response to ectopic expression of CCL21 and CXCL13, respectively (37). The central role of B cells in initiating allograft-TLO formation would seem to be supported by experimental and biopsy-based studies within the last decade showing that TLOs within kidney, heart, or lung grafts are predominantly composed of B cell clusters organized into follicles, segregated from $\mathrm{T}$ cell and plasma cell areas $(32,38-44)$. Further analysis has revealed that TLOs can closely resemble a classical secondary follicle, consisting of proliferating $\left(\mathrm{Ki}^{+} 7^{+}\right) \mathrm{B}$ cells in close proximity to CXCL13 and supported by a network of follicular dendritic cells (FDCs), surrounded by naïve follicular mantle $\left(\operatorname{IgD}^{+}\right)$B cells (45-49). Such ectopic GCs have been consistently found within chronically rejecting allografts $(32,40,45)$ and have been identified in autoimmune-associated TLOs within peripheral tissues (50-52). A LT $\alpha \beta$-dependent LTi-like role for $\mathrm{B}$ cells in the development of TLOs has also been described in dextran sulfate sodium-induced colitis (29).

What, however, governs the infiltration and survival of B cells in allografts and drives them to form TLOs? Recipient-derived $B$ cells and B cell clusters (along with B cell transcripts) have been found in acute and chronically rejecting solid organ allografts where they can contribute to both humoral and cellular allograft rejection (53-56). Chemokines and chemokine receptors are critical in leukocyte recruitment, activation, and differentiation, with CXCL10 ligand and its receptor CXCR3 (57) as well as CXCL13 and CXCR5 (58) and chemokine receptor CCR1 (59) governing the recruitment of B cells. Gene expression profiling of renal allograft biopsies has shown that expression of these chemokines plus their corresponding receptors is strongly correlated with rejection than with stable allograft function (60). 


\section{Auto- or Allo-antigen induced inflammation}

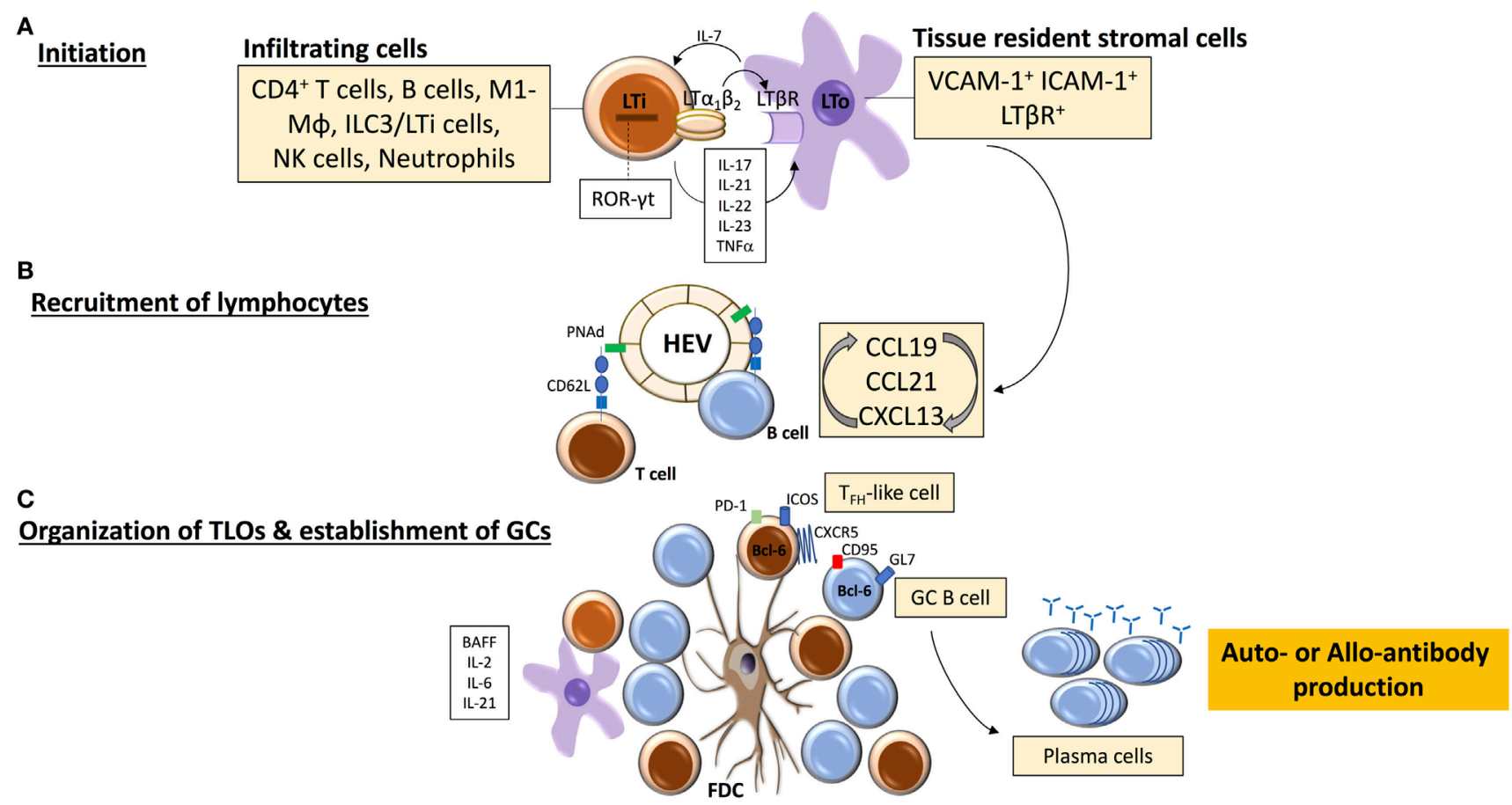

FIGURE 1 | Tertiary lymphoid organ (TLO) initiation and formation. (A) TLO-initiating immune cells [among which are lymphoid tissue inducer (LTi)-like cells] accumulate at sites of inflammation and interact with stromal mesenchymal lymphoid tissue organizing (LTo) cells. The binding of LT $\alpha_{1} \beta_{2}$ on LTi cells with LT $\beta R$ on LTo cell leads to the release of chemokines CCL19, CCL21, and CXC-chemokine ligand 13 (CXCL13) that mediate further immune cell recruitment and spatial organization within the forming TLO. (B) Similarly, local release of homeostatic chemokines drives the formation of high endothelial venules (HEVs) and lymphangiogenesis, leading to homing of (auto-or alloreactive) naïve and memory B and T cells. A well-organized TLO is composed of compartmentalized T and B cell areas, follicular dendritic cells (FDC), dendritic cells, HEVs, and lymphatic vessels. (C) Under the influence of LT $\boldsymbol{\alpha}_{1} \beta_{2}$, stromal cells acquire the phenotypic and functional properties of FDCs, which facilitate persistent antigen presentation within TLOs, and CD4+ $T$ cells acquire follicular helper $\left(T_{F H}\right)$-like effector characteristics (CXCR5 ${ }^{\text {hi }}$ PD- $1^{\text {hil }} \mathrm{COS}^{\text {hi }}$ ) to drive activation of B cells. Cytokines, such as B-cell-activating factor (BAFF), IL-21, and IL-6, contribute to the survival and maintenance of $\mathrm{T}_{\mathrm{FH}}$ cells and germinal center (GC) B cells, which subsequently differentiate into antibody-secreting plasma cells.

A recent meta-analysis has shown that the presence of $\mathrm{CD} 20^{+}$ B cell infiltrates within allografts was correlated with more aggressive and steroid-resistant graft rejection and with an increased risk of graft loss (61). Zarkhin and Sarwal performed immunostaining on transplant nephrectomy microarray samples for B cell phenotypes and found two lineages of B cells: interstitial $\mathrm{CD} 20^{+} \mathrm{B}$ cell clusters, most of which had an activated phenotype as they were positively stained with CD79a, and scattered CD38 ${ }^{+}$ plasmablasts and plasma cells $(53,62)$. The B cell clusters also stained for MHC class II (HLA-DR) and were surrounded by $\mathrm{CD}^{+} \mathrm{T}$ cells, suggesting a role for local antigen presentation by $\mathrm{B}$ cells. The antigen-presenting function of infiltrating $\mathrm{B}$ cells (63) might contribute to an augmented alloreactive response and thus drive aggressive $\mathrm{T}$ cell-mediated cellular rejection by activating alloreactive $\mathrm{T}$ cells into effector and memory cells $(40,64)$. This hypothesis is supported by studies showing a strong correlation between scattered $\mathrm{CD}^{+} \mathrm{T}$ cells and $\mathrm{CD} 20^{+} \mathrm{B}$ cell infiltrates in renal allografts during acute rejection (65). These $B$ cell infiltrates within the transplant can then initiate formation of intra-graft TLOs. It should be noted, however, that other studies that have failed to show a correlation between CD20 ${ }^{+}$
B cell infiltration or immunoglobulin transcript expression in acute rejection and poor late graft function $(56,65)$ implying that $\mathrm{B}$ cells and plasma cells can be recruited and retained in inflammatory compartments in allografts as a nonspecific feature of chronic inflammation. The lifespan of antibody-secreting plasma cells depends upon residence in a survival niche, such as the bone marrow and to a lesser extent, the red pulp of the spleen $(66,67)$. In conventional immune responses, the migration of post-GC plasma cells from SLOs to the bone marrow depends on the interaction between CXCR3 and CXCR4 on plasma cells and CXCL9, CXCL10, and CXCL12 produced by bone marrow stroma $(68,69)$. Inflammation within an allograft can similarly create a chemokine and cytokine rich niche (60) to support long-term plasma cell survival, so it is, therefore, possible that intra-graft plasma cells originate within conventional lymphoid tissue rather than within TLOs and migrate to the inflammatory milieu within the allograft, as has been described for plasma cells within inflamed kidneys in a mouse model of Systemic Lupus Erythematosus (70). However, given the intimately close proximity of plasma cells to ectopic GCs $(31,32,43,71,72)$, this possibility would seem to be less likely. 
Evidence to support the potential role of B cells in TLO formation has come from studies examining their role in the maintenance of SLO architecture in adults. LT $\beta$ expression can be upregulated in B cells following antigen engagement and by chemokine CXCL13 signaling (73), and it has been shown that the absence of LT-expressing B cells results in the inability of isolated lymphoid follicles (B cell follicle-containing lymphoid structures along the length of the mesenteric wall of the small intestine) to develop fully, suggesting that B cells participate in the development of mucosal lymphoid tissue (74). B cells have been shown to deliver the signals necessary for both the maintenance of lymphoid follicles within SLOs in adult animals as well as the maturation of FDCs (75). It was initially unclear if naïve B cells can express $\operatorname{LT} \alpha_{1} \beta_{2}(76,77)$. Although naïve B cells express LT $\beta$ constitutively (78), expression of the LT $\alpha$ subunit requires stimuli such as CD40L (79), IL-4 (79) or endotoxin (80). Similarly, LT $\alpha$ expression on $\mathrm{T}$ cells is upregulated after activation of the $\mathrm{T}$ cell receptor by anti-CD3 and by CCL21 $(37,81)$. The role of B cells in this process has been further dissected by preventing $B$ cells from expressing $\operatorname{LT} \alpha_{1} \beta_{2}$, by selectively deleting the LT $\beta$ gene in B cells (B-LT $\beta$ knockout mice) (82). Splenic B cell follicles and FDC networks are disrupted in these animals, and even though GCs can develop in response to antigenic stimuli, albeit somewhat reduced in size and number, IgG responses are impaired. These findings imply that B cells, via membrane-bound $\mathrm{LT} \alpha_{1} \beta_{2}$, transmit signals required for the development and function of stromal cells that produce chemokines essential for normal SLO organization, and so could also extend to B cell involvement in initiating TLO formation.

A further question to consider is the profile of adult lymphocytes that initiate and maintain TLOs-are they naïve or activated cells? One of the hallmark characteristics of SLOs is their exquisite ability to recruit circulating naive lymphocytes and elicit priming and subsequent clonal expansion of antigenspecific $\mathrm{T}$ and $\mathrm{B}$ cells $(1,83)$. In general, naive lymphocytes circulate among SLOs; in LNs this occurs via binding of L-selectin/ CD62L with a family of mucin-like sulfated glycoproteins, also known as peripheral node addressins (PNAd), on HEVs (84), resulting in lymphocyte rolling on the endothelium, which represents the first step in homing to LNs. Antigen-experienced (primed) lymphocytes, however, as a result of interaction with antigen-presenting cells, modify their expression of adhesion molecules and chemokine receptors (e.g., CD62L and CCR7) and have different migratory patterns (85). The expression of specific combinations of these receptors allows primed lymphocytes, including memory $\mathrm{T}$ cells, to interact with blood vessel endothelium and to migrate into peripheral tissues for responses to inflammatory stimuli (86). Whether TLOs maintain an immune response that originates from circulating activated $\mathrm{B}$ and/or $\mathrm{T}$ cells and/or from naive cells remains to be fully defined. As HEVs are a fundamental constituent of conventional LNs that permit naive lymphocyte egress from the circulation for adaptive immune responses (87), HEVs in allograft-TLOs $(32,39,88)$ could have important pathological consequences, as they could facilitate entry of naïve T and B cells (previously excluded by the absence of cognate ligands for CCR7 and L-selectin) and also central memory T cells, by way of their expression of CD62L (89), and allow an alternative site for lymphocyte priming, activation, and effector function (64). However, it is more plausible that the initial ingress of lymphocytes that establish TLOs along with HEVs comprise an effector population; in support the majority of the infiltrating B cells in renal allografts display activated $\left(\mathrm{CD} 79^{+}\right)$and memory $\left(\mathrm{CD} 27^{+}\right)$ phenotypes (62). From our experimental work, we have shown that fully mature allograft-TLOs fail to form in B cell deficient animals; ectopic lymphoid aggregates do form (presumably a consequence of the cellular alloimmune response) but were not well circumscribed and importantly lacked HEVs, implying that B cells are critical for TLO formation but as an activated, rather than naive, population (32). Therefore, it is likely that naïve recipient B cells, initially primed by alloantigen in SLOs, migrate to allografts after altering their expression of adhesion molecules and interact with resident (recipient) stromal cells to establish of a chemokine-directed positive feedback loop that orchestrates further lymphocyte recruitment and organization and formation of HEVs (73). B cells, upon sustained antigenic challenge in chronically inflamed tissues, can upregulate LT expression through IL-4R $\alpha$ signaling and promote the proliferation and activation of supporting fibroblastic reticular cells (FRCs) via LT $\beta$ R signaling (90). FRCs can in turn secrete T cell chemokines, generate support structures for migrating $\mathrm{T}$ cells and dendritic cells (91) and form a conduit to distribute small soluble antigens throughout lymphoid organ parenchyma $(92,93)$. Moreover, FRCs enhance the survival of naive T cells by producing IL-7 (94), present antigen to T cells (95), and support the differentiation of regulatory dendritic cells (96). As a result, lymphocytic infiltrates in chronically inflamed tissues can eventually acquire the structural characteristics to develop into a lymphoid organ to support further lymphocyte recruitment and retention (see also Figure 1). In addition to the role of lymphoid chemokines, cytokines produced within the inflammatory milieu of an allograft or peripheral organ affected by autoimmunity support the development of TLOs and compartmentalization into T and $\mathrm{B}$ cell areas, and can also contribute to the transcriptional regulation of CXCL13, CCL19, and CCL21. Of note, IL-17, IL-21, IL-22, IL-23, and TNF have all been shown to be important (36, 97-103), with the level of certain pro-inflammatory cytokines correlating with disease outcomes (104).

\section{The Other Cast Members for TLO Initiation - T Cells and Innate Immune Cells}

Besides B cells, a variety of $\mathrm{T}$ cells and innate immune cells are also involved in ectopic lymphoid neogenesis independent of lymphoid-tissue inducer cells. In particular, Il-17 producing $\mathrm{CD}^{+}$Th17 cells have been shown to be essential for the formation of TLOs in the central nervous system of mice during chronic experimental autoimmune encephalomyelitis (EAE), where stromal LT $\beta$ R signaling promoted extracellular matrix deposition, $\mathrm{T}$ cell effector cytokine responses, and chemokine production that supported meningeal leukocyte accumulation (105), and for responses against collagen (V) protein to induce the development of bronchiolitis obliterans 
after lung transplantation (106). Furthermore, there is a correlation between activation-induced cytidine deaminase (AID)expressing ectopic GCs within chronically rejecting kidney allografts and the cytokine IL-21, suggesting that Th17 cells have a role to play in lymphoid neogenesis (107). IL-21 secretion from Th17 cells (108) can stimulate B cells through the generation of $\mathrm{T}_{\mathrm{FH}}$ cells $(109,110)$, the importance of which will be discussed in a later section.

A key player in innate immune responses are macrophages and not only can they act as antigen-presenting cells within TLOs (111), and produce CXCL12 to drive migration of CXCR4 ${ }^{+}$centroblasts to the dark zone in ectopic GCs (99), they can also initiate TLO formation; in particular, M1-polarized pro-inflammatory macrophages can substitute for LTi cells and trigger chemokine expression by vascular smooth muscle cells (similar to that produced by LTo cells) independently of LT $\beta$ R signaling (35). Monocytes and macrophages also secrete CXCL13 in TLOs associated with rheumatoid arthritis and ulcerative colitis (112), providing a rich source of lymphoid chemokines in chronic inflammation. CXCL13 can be expressed within and near smaller collections of B cells in diseased tissue where no FDCs or HEVs are detected, suggesting that CXCL13 production by monocytes could be an early event in lymphoid neogenesis. Similarly, accumulations of macrophages within the lumens of capillaries and small vessels of the myocardial interstitium are a prominent feature of cardiac allograft antibody-mediated rejection (AMR) (113) and tubulointerstitial cellular rejection (Banff category 4, type I) in renal allografts (114), with presence of macrophages in early biopsies predictive of interstitial fibrosis/tubular atrophy and subsequent graft failure (115-117). Besides acting as a source of CXCL13 to promote development of $\mathrm{CXCR}^{+} \mathrm{B}$ cell aggregates in chronically rejecting cardiac allografts (46), infiltrating macrophages can also transdifferentiate into lymphatic endothelial cells or secrete vascular endothelial growth factor to drive the growth of lymphatic vessels (LVs) through the sprouting of preexistent lymphatics $(118,119)$. The significance of lymphangiogenesis in transplantation was shown in a study by Kerjaschki and colleagues who identified vast amplification of LVs near or within TLOs in renal allografts with acute rejection (41).

\section{The Counterpart to the Initiators- Stromal Organizer Cells}

The counterparts to the initiators cells in the development of SLOs are stromal organizer cells (10). LTi cells, through expression of surface $\operatorname{LT} \alpha_{1} \beta_{2}$, activate mesenchymal stromal cells via LT $\beta$ R signaling to express adhesion molecules, such as ICAM1, VCAM1, MAdCAM1, and PNAd, and a set of homeostatic chemokines (CCL19, CCL21, CXCL12, and CXCL13), which then allows them to be retained in the developing organs and will regulate further lymphocyte homing and compartmentalization (13). After birth, LTo cells undergo further differentiation into various non-hematopoietic stromal subtypes present in the adult SLO, such as FRCs of the T cell zone, FDCs within B cell follicles and GCs, and marginal reticular cells adjacent to the subcapsular sinus (120). LN stromal endothelial cells can differentiate into either blood endothelial cells (HEVs) or lymphatic endothelial cells (121). Subsequently, these structures are colonized by lymphocytes resulting in a highly organized lymphoid organ.

Stromal organizer cells are mesenchymal in origin, with many cell types capable of playing this role (122); these include fibroblasts, pericytes (a type of smooth muscle cell commonly found surrounding capillaries and HEVs in LNs), blood and lymphatic endothelial cells, and epithelial cells. Stromal cells also play a critical role in TLO formation in that they provide an environment that is conducive to lymphoid neogenesis (25, 123-126); their characteristics and function have been the subject of two recent comprehensive reviews $(127,128)$. TLOs commonly arise close to vascular or epithelial ductal structures adjacent to smooth muscle cells or myofibroblast-like cells that share features with conventional LTo cells, e.g., synovial fibroblasts from patients with rheumatoid arthritis display LTo-like properties, including expression of LT $\beta R$ and the production of homeostatic chemokines (e.g., CXCL13) (129) and B-cell-activating factor (BAFF) to support synovial B cell responses (130), and LT $\beta$ R signaling has been shown to induce aortic smooth muscle cells to form TLOs in atherosclerosis (71). Nevertheless, LT signaling is not absolutely required for activation of stromal cells and leukocytes other than lymphocytes can activate resident tissue fibroblasts (126). Moreover, it is also possible that circulating fibrocytes may be recruited by homeostatic chemokines to sites of TLO development (131). It has subsequently been proposed that stromal cell activation in TLO formation is a two-step process: the inflammatory cytokine milieu initially primes local resident stromal cells independent of LT signaling and maturation to LTo-like cells occurs as a result of signaling by LT-expressing immune cells, resulting in the generation of homeostatic chemokines that promote lymphocyte compartmentalization $(127,128)$. The activated stromal cells can also influence the type of immune responses; for instance, activated fibroblasts can secrete IL-6 which is required for the induction and maintenance of $\mathrm{T}_{\mathrm{FH}}$ cells (132) and can induce T cell tolerance by presenting high levels of peptide-MHC class II complexes (133), thus suggesting an immunoregulatory role for stromal cells in the context of TLO development.

\section{HEVs-A Vascular Component of the Stromal Network}

High endothelial venules are an integral part of the stromal network of LNs and as mentioned above they facilitate the trafficking of naive recirculating $\mathrm{B}$ and $\mathrm{T}$ lymphocytes from the circulation. HEVs are prominent features of TLOs and their presence can be considered the defining characteristic that distinguishes lymphocyte aggregates from other forms of inflammatory infiltrate (39). The characteristics of HEVs in TLOs have been extensively reviewed elsewhere $(88,134)$, and although HEVs in TLOs express the same chemokines [e.g., CCL19, CCL21 (135)], adhesion molecules [e.g., ICAM-1 (72)], and ligands [e.g., PNAd $(32,136)$ and MAdCAM-1 $(32,72)]$ as those in conventional LNs, it is important to point out that the actual migration of 
intra-vascular naïve lymphocytes from the systemic circulation via HEVs in allograft-TLOs into the parenchyma of an organ has not yet been visualized. The development of mice with red fluorescent LVs and green fluorescent HEVs (137) and their in vivo imaging in SLOs (138) will enable similar analysis in TLOs and resolve whether HEVs function as sites of entry for naïve alloreactive lymphocytes into ectopic lymphoid tissue to undergo activation and differentiation into effector and memory cells.

The precise mechanisms and signaling molecules besides LT $\alpha_{1} \beta_{2}$ that drive stromal cell activation and differentiation in TLOs are not yet fully defined and the identity of LTo cells remains somewhat elusive as they lack specific markers and so have not yet been isolated from TLOs. Several questions also remain unanswered. First, do tissue stromal cells convert to a "lymphoid-like" phenotype as a result of inflammation (126), or do they arise in TLOs from progenitors such as mesenchymal stem cells? Second, is the chemokine expression by stromal cells a result of ingress of LT-expressing (alloreactive) lymphocytes or does the lymphoid stroma undergo expansion prior to the infiltration of lymphocytes? Third in the context of transplantation, do stromal cells arise from resident cells in the allograft or are they derived from the recipient? And fourth, what signaling pathways can be targeted to manipulate TLO stromal cells? Transplantation provides a unique opportunity to answer some of these questions as based on the above it would seem likely that recipient-derived lymphocytes interact with donor derived stromal cells to establish TLOs. This could be analyzed by selectively ablating donor-derived stromal cells without impacting lymphoid stroma in (recipient) SLOs, for example by using donors lacking expression of LT $\beta$ R (139) or by conditionally depleting fibroblasts in allografts either based on their expression of the diphtheria toxin receptor (140) or by using inducible transgenic mice [Ccl19-Cre $\times$ iDTR] (141).

\section{THE FUNCTIONAL SIGNIFICANCE OF THE B CELL COMPONENT WITHIN SLOS}

As discussed above, the prominence of follicular structures within the TLO may reflect an integral role for the B cell in its formation, most likely as a source of membrane-bound LT (142, 143). Nevertheless, the presence of B cell follicles raises important questions relating to the function they provide; most critically, whether the humoral response within the TLO is simply an extension of those occurring synchronously in SLOs or whether it provides unique and distinct capabilities. If the former, a simple consideration of the respective volume of lymphoid tissue within the TLO and SLO would suggest it unlikely that the TLO response will materially impact upon either the nature or strength of the global humoral response. "Distinctiveness" of the humoral TLO response is likely determined by the nature of the GC component, because of the more sophisticated output-the production of affinity-matured memory B cells and LLPCs-that the GC generates (144). In this respect, while it is clear that immunohistochemical features of the GC response, such as expression of AID and presence of FDCs and GC-phenotype B cells, have been described within TLO (32, 71, 145-157), important differences from conventional (SLO-resident) GC appearances have also been noted (discussed below).

Over the last decade, a number of seminal publications have substantially improved our understanding of the conventional GC response [reviewed in Ref. (158-163)]. By detailing some of the molecular pathways responsible for coordinating the GC response, these publications have reinforced that the anatomical constraints, namely the physical segregation of the GC into light and dark zones, are integral for GC function. The greater insights provided by these studies, thus, enable a timely reappraisal of the likely function of the GC response within TLOs. To do so, it is first necessary to consider how our understanding of the GC response has evolved.

\section{The Initiation and Maintenance of Conventional GC Responses within SLOs}

Following encounter with target epitope, antigen-specific $\mathrm{T}$ and $\mathrm{B}$ cells migrate to the T-B cell border (164) or interfollicular zone (165) as a consequence of alterations in sensitivity to the CCR7 ligands, CCL19, and CCL21 (166). Following robust proliferation, responding $B$ cells either seed the extrafollicular response in LN medullary cords and the red pulp in the spleen (167), or a relatively small proportion migrates back to the follicle to seed the GC response (168). Retention within the follicle is maintained by downregulating expression of the orphan G protein-coupled receptor Ebi2 $(169,170)$ and induction of the sphingosine 1-phosphate receptor, S1P2 $(171,172)$. The determinants for clonal selection to the follicle remain unclear, because although it has been reported that highaffinity clones may have a selection advantage (173), this has been similarly proposed for the extrafollicular focus (174). Analysis, moreover, of hyper-mutated broadly neutralizing antibodies to HIV has highlighted that the germline configuration may have only minimal reactivity (175). Two recent publications have instead suggested that seeding of the GC is largely stochastic $(176,177)$.

The small number of clones that seed the nascent GC become a foci of proliferating blasts leading to the formation of the archetypal light and dark zones, first identified by light microscopy over 80 years ago (178). Within the dark zone, CXCR $4{ }^{\text {hi }} \mathrm{CD} 83^{\text {lo }} \mathrm{CD} 86^{\text {lo }}$ "centroblasts" are retained by CXCL12expressing reticular cells (179-181) and undergo between, typically, one and six rapid divisions $(182,183)$. Expression of AID and upregulation of Pol $\eta$ DNA polymerase introduces point mutations into the genes encoding the $\mathrm{B}$ cell receptor (BCR) $(180,184)$ : the dark zone is, therefore, the region where immunoglobulin somatic hypermutation (SHM) occurs. Upon egress to the light zone, facilitated by a chemokine gradient toward CXCL13-expressing FDCs, "centrocytes" acquire an activated $\mathrm{CXCR} 4{ }^{\mathrm{lo}} \mathrm{CD} 83^{\mathrm{hi}} \mathrm{CD} 86^{\mathrm{hi}}$ phenotype and reset their antigen-processing machinery (185), prior to encounter with antigen on the surface of the FDC.

Within the light zone, several different outcomes are possible for the centrocyte: death from apoptosis; differentiation to a memory B cell or to a LLPC; and re-entry into the dark zone for a further round of mutation and selection. Although 
many aspects of this process remain poorly understood, it is now clear that the specialized $\mathrm{T}_{\mathrm{FH}}$ subset $(186,187)$ is critical for selection of high-affinity variants within the GC light zone and is the driving force of affinity maturation $(158-160,162)$. $\mathrm{T}_{\mathrm{FH}}$ cell differentiation is initiated by EBi2-guided recognition of target epitope on dendritic cells in the outer $\mathrm{T}$ cell zone, with "quenching" of T cell IL-2 by CD25 on the DC possibly prompting expression of $\mathrm{Bcl} 6(188,189)$, the master transcription factor for $\mathrm{T}_{\mathrm{FH}}$ differentiation (190-192). Subsequent cognate interaction of the pre- $\mathrm{T}_{\mathrm{FH}}$ cell with the antigen-specific $\mathrm{B}$ cell at the T-B cell border, along with co-stimulatory signals delivered through CD28, OX40, and ICOS (193-195), is generally required to complete $\mathrm{T}_{\mathrm{FH}}$ cell differentiation and is critically dependent upon prolonged association between SLAM and SAP family members (196-200): in the absence of SAP, $\mathrm{T}_{\mathrm{FH}}$ do not form. Interestingly, adult $\mathrm{CD}^{+} \mathrm{CD}^{-}$cells residing at the border of the $\mathrm{T}$ cell zone and $\mathrm{B}$ cell follicles have been shown to express OX40L, which helps direct OX40-expressing pre- $\mathrm{T}_{\mathrm{FH}}$ cells into the follicles and induces upregulation of CXCR5 and ICOS expression $(20,194,201)$. CXCR5 ${ }^{\text {hi PD }} 1^{\text {hi }}$ ICOS $^{\text {hi }}$ CD $4 \mathrm{~T}_{\mathrm{FH}}$ cells are then guided to the $\mathrm{B}$ cell follicle under the influence of CXCL13 and EBi2 gradients (202). Migration occurs 1 or 2 days later than the B cell $(165,203,204)$ and of note, this migration is also dependent upon ICOSL signaling from bystander B cells within the follicle; in the absence of this signaling, $\mathrm{T}_{\mathrm{FH}}$ cell migration to the follicle is substantially impaired (205).

A number of recent studies have confirmed the pivotal role that the $\mathrm{T}_{\mathrm{FH}}$ cell plays in affinity maturation of the antibody response $(179,180,182,183,203,204)$. B cells internalize antigen via their BCR for presentation to the helper $\mathrm{T}$ cell in an affinity-dependent manner (206-208), and hence, somatically mutated B cells that have acquired greater amounts of target antigen from the light zone FDC can outcompete other clones for the limiting help available from the GC $\mathrm{T}_{\mathrm{FH}}$ subset (180). These clones can then return to the dark zone for further rounds of mutation and selection. The nature of the signal that the $\mathrm{T}_{\mathrm{FH}}$ provides to the $\mathrm{B}$ cell remains unclear, and likely involves IL-21 (209) and BAFF (210), resulting in both an avoidance of apoptosis within the light zone, as well as a subsequent selection advantage within the dark zone $(179,182,183)$. Thus, availability of $\mathrm{T}$ cell help, rather than access to antigen on the FDC, determines selection of high-affinity variants. From this, one would assume that the $\mathrm{T}_{\mathrm{FH}}$ cell subset would encompass those responding $\mathrm{T}$ cell clones with highest affinity for the peptide complexes presented by the B cell $(211,212)$. However, Shulman et al. have recently suggested that selection into the $\mathrm{T}_{\mathrm{FH}}$ cell population is more permissive, without apparent clonal restriction (203).

Although our understanding of clonal selection within the GC has improved substantially in recent years, with the functional relevance of the GC being primarily a producer of LLPCs and memory B cells, it is perhaps surprising that the triggers governing the generation of these effector populations remain unclear. The progeny of a single B cell can differentiate to seed all the GC and post-GC compartments (213), but LLPCs, first evident as BLIMP-1 expressing "pre-plasma cells" within the GC $(214,215)$, appear to be selected actively from the highest-affinity variants (216-218). Plasma cell differentiation is informed by the signaling tail of the particular immunoglobulin isotype (219), and although it can occur in the absence of T cell help (220), CD40 signaling from cognate interaction with the helper $\mathrm{T}$ cell also appears important $(221,222)$. Krautler et al. have recently proposed that plasma cell differentiation is initiated by highaffinity contact with target antigen, but is thereafter dependent upon receipt of $\mathrm{T}$ cell help (223). By contrast, memory B cells are deposited early, and then continuously, from the GC reaction (218, 224-226). Consequently, compared to the contemporaneous GC B cell, the memory B cell pool exhibits less extensive SHM and its binding affinity for target antigen is much weaker than is observed within the plasma cell output. Memory B cell precursors may arise from low-affinity variants within the light zone, and Shinnakasu et al. have recently reported an inverse correlation with the level of $\mathrm{T}$ cell help delivered and Bach2 expression within the $\mathrm{B}$ cell, and have suggested that relatively high Bach2 expression within lower-affinity centrocytes favors entry to the memory B cell pool (227).

\section{GC Responses within TLOs}

It is, therefore, clear that the GC reaction is remarkably complex, and that its effector functions are dependent upon tight anatomical and temporal control, as evident from the association between dysregulated GC responses and development of humoral autoimmune disease (228-230). This raises the critical questions of whether such sophistication can be recapitulated within an ectopic GC in a peripheral organ, and whether it would match concurrent selection within conventional SLO. This has proven difficult to address experimentally, and although a number of publications have reported anatomical features consistent with GC activity, such as the presence of FDC and AID-expressing B cells with GL7 ${ }^{\text {hi }}$ GC immunophenotype (see Table 1), few studies have attempted to validate GC activity by analyzing effector output. The most robust indicator of GC effector function will be the demonstration of clonal selection with progressive accumulation of high-affinity mutants as a consequence of SHM. It should be stressed that simple clonal restriction within a TLO, whereby TLOs harbor a limited number of B cell clones and these clones differ between individual TLOs, may not itself indicate GC activity; rather it may simply reflect focused seeding of the TLO by locally activated B cells, as reported by Scheel et al. (153). Evidence for SHM within the TLO is, thus, provided by only a handful of studies $(146,154,157)$, with possibly the most convincing a relatively early study by Stott et al. (154), who performed Ig V-region sequencing of B cells recovered by laser microdissection of salivary gland TLOs in human patients with Sjogren's syndrome. Although specific target antigen was not identified, sequencing analysis of the ratio of replacement to silent mutations in the complementarity determining region suggested antigen-mediated selection of high-affinity variants.

As discussed above, the $\mathrm{T}_{\mathrm{FH}}$ cell subset is now known to play a pivotal role in selection of high-affinity variant GC B cells. The $\mathrm{T}_{\mathrm{FH}}$ cell subset is likely to be similarly important for GC TLO function, and as with $\mathrm{B}$ cells in allograft-TLOs, associated $\mathrm{T}_{\mathrm{FH}}$ cells are probably derived from peripheral effector populations 
TABLE 1 | Studies characterizing germinal center (GC)-like structures within tertiary lymphoid organs (TLOs)

\begin{tabular}{|c|c|c|c|c|c|c|c|c|}
\hline & \multirow{2}{*}{$\begin{array}{l}\text { System } \\
\text { Species/organ }\end{array}$} & \multicolumn{4}{|c|}{ Structure and cells } & \multicolumn{2}{|c|}{ Diverification } & \multirow[t]{2}{*}{ Notes } \\
\hline & & $\begin{array}{c}\text { High } \\
\text { endothelial } \\
\text { venules (HEV) }\end{array}$ & $\begin{array}{l}\text { Follicular } \\
\text { dendritic cells } \\
\text { (FDC) }\end{array}$ & $\begin{array}{l}B \text { cells/GC } \\
\text { markers }\end{array}$ & $\mathrm{T}$ cells $/ \mathrm{T}_{\mathrm{FH}}$ & $\begin{array}{l}\text { Evidence of somatic } \\
\text { hypermutation } \\
\text { (SHM) }\end{array}$ & $\begin{array}{l}\text { Increased mRNA/protein } \\
\text { expression }\end{array}$ & \\
\hline $\begin{array}{l}\text { Motallebzadeh } \\
\text { et al. (32) }\end{array}$ & Murine/heart Tx & Y & Y & B220/PNA & $N R$ & $N R$ & $\begin{array}{l}\text { NR/activation-induced cytidine } \\
\text { deaminase (AID) }\end{array}$ & $\begin{array}{l}\text { Blocking lymphotoxin (LT) signaling by } \\
\text { LTRR-lg impairs TLO development and } \\
\text { effector antibody response }\end{array}$ \\
\hline $\begin{array}{l}\text { Thaunat } \\
\text { et al. (31) }\end{array}$ & Human/kidney Tx & Y & Y & CD20/BcL-6 & CD3 & $\mathrm{N}$ & $\begin{array}{l}\text { AID, CXC-chemokine ligand } \\
13 \text { (CXCL13), CXCR4, } \\
\text { CC-chemokine ligand } 19 \\
\text { (CCL19), CCL21, CCR7, } \\
\text { LT } \alpha, \text { LT } \beta \text {, and CXCR5 }\end{array}$ & $\begin{array}{l}\text { Extensive characterization of gene } \\
\text { expression involved in lymphoid } \\
\text { oranogenesis }\end{array}$ \\
\hline $\begin{array}{l}\text { Grabner } \\
\text { et al. (71) }\end{array}$ & Murine/ApoE Aorta & Y & Y & B220/Ki-67 & CD3 & $N R$ & CXCL13, CCL21, Ltb & $\begin{array}{l}\text { CD138+-Plasma cells, Tregs } \\
\text { No antibody characterization }\end{array}$ \\
\hline $\begin{array}{l}\text { Clement } \\
\text { et al. (145) }\end{array}$ & $\begin{array}{l}\text { Murine/ } \\
\text { ApoE aorta } \\
\text { Human/AAA }\end{array}$ & $\begin{array}{l}\text { NR } \\
\text { Y }\end{array}$ & $\begin{array}{l}\text { NR } \\
Y\end{array}$ & $\begin{array}{l}\text { B220/CD95 } \\
\text { CD20/PNA }\end{array}$ & $\begin{array}{l}\text { CD4/ } \\
\text { CXCR5+PD-1+ } \\
\text { CD4/CXCR5, } \\
\text { ICOS, PD-1 }\end{array}$ & $\begin{array}{l}\mathrm{NR} \\
\mathrm{NR}\end{array}$ & $\begin{array}{l}\mathrm{NR} \\
\mathrm{NR}\end{array}$ & $\begin{array}{l}\mathrm{CD}^{+} \text {regulatory T cells regulate } \\
\text { secondary lymphoid organ (SLO) } \\
\text { and TLO responses }\end{array}$ \\
\hline $\begin{array}{l}\text { Vu Van } \\
\text { et al. (146) }\end{array}$ & Murine/iBALT & $N R$ & $\mathrm{Y}$ (very low) & $\begin{array}{l}\text { CD19/GL7, } \\
\text { PNA, Bcl6, } \\
\text { Cd38' }\end{array}$ & $\begin{array}{l}\text { Th-like but no } \\
\text { CXCR5 } 5+B C L- \\
6^{+} T_{F H}\end{array}$ & Yes & $N R$ & $\begin{array}{l}\text { FDC not associated with GC B cells; } \\
\text { SHM (NP as target), but no } \\
\text { comparison to SLO } \\
\text { High CD138 plasma cells }\end{array}$ \\
\hline $\begin{array}{l}\text { Germain } \\
\text { et al. (147) }\end{array}$ & $\begin{array}{l}\text { Human/lung } \\
\text { tumor }\end{array}$ & & Y & $\begin{array}{l}\text { CD2O/Ki-67, } \\
\mathrm{Bcl}-6\end{array}$ & CD3 & $N R$ & AID & $\begin{array}{l}\text { Described } \mathrm{CD} 23^{+} \text {mantle zone, } \mathrm{CD} 138 \\
\text { plasma cells at the periphery of TLO B cell } \\
\text { density in TLOs as prognostic biomaker }\end{array}$ \\
\hline $\begin{array}{l}\text { Martinet } \\
\text { et al. (231) }\end{array}$ & Human/solid tumors & Y & $N R$ & CD20/NR & CD3 & $N R$ & $\begin{array}{l}\text { CCL19, CCL21, CXCL13, } \\
\text { and CCR7 }\end{array}$ & $\begin{array}{l}\text { Large-scale FACS analysis on immune } \\
\text { populations retrieved from TLOs revealed } \\
\text { that tumor HEVs are associated with } \\
\text { increased numbers of effector (cytotoxic, } \\
\text { and memory) and naiive T cells }\end{array}$ \\
\hline $\begin{array}{l}\text { Cipponi } \\
\text { et al. (232) }\end{array}$ & $\begin{array}{l}\text { Human/ } \\
\text { melanoma }\end{array}$ & Y & Y & $\begin{array}{l}\text { CD20, CD138, } \\
\text { AID, Ki-67 }\end{array}$ & NR & Yes & AID & $\begin{array}{l}\text { While cutaneous metastic lesions } \\
\text { contained TLOs, primary melanomas } \\
\text { lacked B cell clusters but contained } \\
\text { HEVs. TLO-derived lg gene repertoire } \\
\text { demonstrated clonal amplification, SHM, } \\
\text { and isotype switching }\end{array}$ \\
\hline $\begin{array}{l}\text { Coppola } \\
\text { et al. (233) }\end{array}$ & $\begin{array}{l}\text { Human/colorectal } \\
\text { cancers (CRC) }\end{array}$ & $N R$ & Y & CD20/Ki-67 & CD3 & $N R$ & $\begin{array}{l}\text { CCL2, CCL3, CCL4, CCL5, } \\
\text { CCL8, CCL18, CCL19, } \\
\text { CCL21, CXCL9, CXCL10, } \\
\text { CXCL11, and CXCL13 }\end{array}$ & $\begin{array}{l}\text { Extensive metagene analysis using gene } \\
\text { chip technology, and } 12 \text {-chemokine gene } \\
\text { screening was performed on } 326 \text { CRCs } \\
\text { suggested that TLO structures } \\
\text { are associated with better prognosis }\end{array}$ \\
\hline $\begin{array}{l}\text { de Chaisemartin } \\
\text { et al. (234) }\end{array}$ & $\begin{array}{l}\text { Human/lung } \\
\text { tumor }\end{array}$ & Y & Y & CD138 & $\mathrm{CD} 4, \mathrm{CD} 62 \mathrm{~L}$ & $N R$ & $\begin{array}{l}\text { CCL19, CCL21, CXCL13, } \\
\text { CCL17, CCL22, IL-16, } \\
\text { ICAM-2, ICAM-3, ICAM-1, } \\
\text { and MadCAM-1 }\end{array}$ & $\begin{array}{l}\text { Characterization of adhesion molecules } \\
\text { and chemoattractants of lymphoid cells } \\
\text { into lung cancer tissue }\end{array}$ \\
\hline
\end{tabular}


TABLE 1 | Continued

\begin{tabular}{|c|c|c|c|c|c|c|c|c|}
\hline & \multirow{2}{*}{$\begin{array}{l}\text { System } \\
\text { Species/organ }\end{array}$} & \multicolumn{4}{|c|}{ Structure and cells } & \multicolumn{2}{|c|}{ Diverification } & \multirow[t]{2}{*}{ Notes } \\
\hline & & $\begin{array}{c}\text { High } \\
\text { endothelial } \\
\text { venules (HEV) }\end{array}$ & $\begin{array}{l}\text { Follicular } \\
\text { dendritic cells } \\
\text { (FDC) }\end{array}$ & $\begin{array}{l}\text { B cells/GC } \\
\text { markers }\end{array}$ & $\mathrm{T}$ cells $/ \mathrm{T}_{\mathrm{FH}}$ & $\begin{array}{l}\text { Evidence of somatic } \\
\text { hypermutation } \\
\text { (SHM) }\end{array}$ & $\begin{array}{l}\text { Increased mRNA/protein } \\
\text { expression }\end{array}$ & \\
\hline $\begin{array}{l}\text { Slight } \\
\text { et al. (148) }\end{array}$ & Murine/lung TB & & Y & $\begin{array}{l}\text { B220/PCNA, } \\
\text { PNA }\end{array}$ & $\mathrm{CD} 4 / \mathrm{T}_{\mathrm{FH}}$ & NR & CXCL13 & $\begin{array}{l}\text { TLO contained Th1-like cells; CD4+ } \\
\text { CXCR5 }{ }^{+} \text {T cells is essential for TLO } \\
\text { localization }\end{array}$ \\
\hline $\begin{array}{l}\text { Bombardieri } \\
\text { et al. (149) }\end{array}$ & $\begin{array}{l}\text { Murine/SS induction } \\
\text { via ADV5 delivery }\end{array}$ & Y & Y & B220/GL7 & CD3 & NR & $\begin{array}{l}\text { AID, CXCL13/CXCR5, CCL19/ } \\
\text { CCR7, and LT- } \beta\end{array}$ & No antibody characterization \\
\hline $\begin{array}{l}\text { Gu-Trantien } \\
\text { et al. (150) }\end{array}$ & Human/breast cancer & NR & Y & CD20/Ki67 & $\begin{array}{l}\mathrm{CD} 4 / T_{\mathrm{FH}} \\
\text { phenotype }\end{array}$ & NR & CD200, CXCL13, ICOS, PD1 & $\begin{array}{l}\text { TLO contained Th1, Th2, Th17, Tregs, } \\
\text { and memory T cells }\end{array}$ \\
\hline \multirow{2}{*}{$\begin{array}{l}\text { Nacionales } \\
\text { et al. (151) }\end{array}$} & \multirow{2}{*}{$\begin{array}{l}\text { Murine/TMPD } \\
\text { lipo-granuloma }\end{array}$} & \multirow[t]{2}{*}{ NR } & \multirow[t]{2}{*}{ N } & \multirow[t]{2}{*}{ B220/Ki-67 } & \multirow[t]{2}{*}{ CD3 } & \multirow[t]{2}{*}{ Y } & \multirow{2}{*}{$\begin{array}{l}\text { AID expression } \\
\text { splenocytes > TLO > peritoneal } \\
\text { exudate cells }\end{array}$} & Antigen-driven SHM \\
\hline & & & & & & & & CSR (excision circles) \\
\hline $\begin{array}{l}\text { Cheng } \\
\text { et al. (152) }\end{array}$ & Human/kidney Tx & NR & NR & CD20 & NR & Y & Rag-1, Rag-2, & $\begin{array}{l}\text { Antigen-driven SHM; clonal restriction in } \\
\text { peripheral, and TLO-derived lg genes }\end{array}$ \\
\hline $\begin{array}{l}\text { Scheel } \\
\text { et al. (153) }\end{array}$ & $\begin{array}{l}\text { Human/RA B cells } \\
\text { synovial fluid }\end{array}$ & $\mathrm{N}$ & $\mathrm{N}$ & N & NR & Y & NR & $\begin{array}{l}\text { Synovial fluid lacked GC formation, but } \\
\text { contained } B / T \text { cells aggregates. Plasma } \\
\text { cells aggregates are the consequence of } \\
\text { migration of plasmablasts from peripheral } \\
\text { lymphoid organs }\end{array}$ \\
\hline $\begin{array}{l}\text { Stott } \\
\text { et al. (154) }\end{array}$ & $\begin{array}{l}\text { Human/SS salivary } \\
\text { glands }\end{array}$ & NR & Y & CD2O & CD3 & Y & NR & $\begin{array}{l}\text { Important reported LZ/DZ, large numbers } \\
\text { of plasma cells in surrounding tissue }\end{array}$ \\
\hline $\begin{array}{l}\text { Grewal } \\
\text { et al. (155) }\end{array}$ & $\begin{array}{l}\text { Murine/salivary gland } \\
\text { inoculation with CMV }\end{array}$ & NR & Y & $\begin{array}{l}\text { B220/GCT, } \\
\text { GL7, PNA, } \\
\text { Ki-67 }\end{array}$ & CD4 & Y & $\begin{array}{l}\text { AID, CXCL13 (lymphoid } \\
\text { neogenesis), syndecan-1, } \\
\text { Blimp-1, PAX5 }\end{array}$ & $\begin{array}{l}\text { Possible LZ/DZ development but not } \\
\text { formally addressed }\end{array}$ \\
\hline $\begin{array}{l}\text { Corsiero } \\
\text { et al. (156) }\end{array}$ & Human/RA & NR & NR & CD20, CD138 & CD3 & Y & CXCRL13, CXCR5, LT- $\beta$ & $\begin{array}{l}\text { CD19+ FACS sorting of VH/NL } \\
\text { sequencing reviled affinity maturation } \\
\text { and clonal diversity }\end{array}$ \\
\hline $\begin{array}{l}\text { Weinstein } \\
\text { et al. (157) }\end{array}$ & TMPD lipo-granuloma & NR & Y & NR & CD3, CD4 & Y & NR & $\begin{array}{l}\text { Affinity maturation possibly less within } \\
\text { TLO, antigen-specific T cells, proliferation, } \\
\text { and cytokine production }\end{array}$ \\
\hline
\end{tabular}

TX, transplantation; iBALT, inducible bronchus-associated lymphoid tissue; ApoE', atherosclerosis-prone apolipoprotein E-knockout; AAA, atherosclerotic aneurysmal arteries; SS, Sjogrens syndrome; TMPD, tetramethyl-pentadecane; $R A$, rheumatoid arthritis; $T B$, tuberculosis. 
(36), but they have not been identified routinely within ectopic lymphoid tissue $(145,148,150,157)$. Indeed, in a murine airway inflammation model, $\mathrm{Vu}$ Van et al. have recently highlighted the presence of an unusual $\mathrm{T}$ cell subset within foci of bronchusassociated lymphoid tissue (146). This subset did not express classical $\mathrm{T}_{\mathrm{FH}}$ cell phenotype, but appeared in close cognate contact with the $\mathrm{B}$ cell fraction, and therefore may resemble a nonclassical $\mathrm{T}_{\mathrm{FH}}$ cell subset, such as the NKT cell subset described recently in relation to anti-lipid antibody responses $(235,236)$. Of note, the help provided by this " $\mathrm{NKT}_{\mathrm{FH}}$ " subset resulted in minimal deposition of LLPCs and suboptimal affinity maturation of the humoral response $(235,236)$. Thus, non-classical $\mathrm{T}_{\mathrm{FH}}$ present with ectopic GCs may be inherently incapable of driving affinity maturation.

Nevertheless, the survival of alloreactive B cells within allograft-TLOs could be supported in particular by IL-21 derived from $\mathrm{T}_{\mathrm{FH}}$ cells, akin to their function within canonical lymphoid tissue. In support of the role of $\mathrm{T}_{\mathrm{FH}}$ cells in allograft-TLOs, Liarski et al. (237) conducted a cell distance mapping study to identify tissue resident $\mathrm{PD}^{+} \mathrm{ICOS}^{+} \mathrm{T}_{\mathrm{FH}}$ cell: $\mathrm{CD} 20^{+} \mathrm{B}$ cell pairs and showed that $80 \%$ of $\mathrm{T}$ cells with a $\mathrm{T}_{\mathrm{FH}}$ phenotype were engaged in tight cognate interactions with $\mathrm{B}$ cells in renal allograft biopsies that displayed features of mixed $\mathrm{T}$ cell-mediated rejection and AMR; by contrast, only $15 \%$ of the T cells were similarly engaged in biopsies with pure $\mathrm{T}$ cell-mediated rejection. Of note, most $\mathrm{B}$ cells in the mixed rejection biopsies were spatially removed from the $\mathrm{T}_{\mathrm{FH}}$ populations, suggesting that only a discrete population of alloreactive $\mathrm{B}$ cells is maintained by $\mathrm{T}_{\mathrm{FH}}$ cells. In addition, the $\mathrm{ICOS}^{+}$-stained cells isolated by laser capture microdissection from mixed rejection samples showed high expression of BATF, a transcription factor necessary for GC formation and maturation of antibody-secreting B cells (238), but Bcl-6 and IL-21, which are critical for $\mathrm{T}_{\mathrm{FH}}$ differentiation and function $(190,239,240)$, were only highly expressed in the samples which had frequent $\mathrm{T}_{\mathrm{FH}}: \mathrm{B}$ cell conjugates. It is, therefore, possible that the $\mathrm{B}$ cells that are juxtaposed to $\mathrm{T}_{\mathrm{FH}}$ cells form TLOs and develop ectopic GCs, inducing Ig SHM and class switching to propagate local humoral alloimmune responses $(146,241,242)$. The importance of $\mathrm{T}_{\mathrm{FH}}$ cells is further evidenced by TLOs in autoimmune disease, where organized GCs containing peanut agglutinin binding GL-7 ${ }^{+}$ $\mathrm{B}$ cells and $\mathrm{ICOS}^{+} / \mathrm{CXCR}^{+} \mathrm{T}_{\mathrm{FH}}$ cells, along with $\mathrm{CD} 138^{+}$plasma cells, have been detected using laser capture microdissection and immunohistochemistry, with their presence correlating with tissue-specific autoantibody formation and progression of disease $(33,34)$. Blockade of $\mathrm{T}_{\mathrm{FH}}$ cell infiltration by interrupting ICOS signaling results in reduced TLO formation associated with atherosclerosis as well as less severe disease progression (145). However, help provided by a classical $\mathrm{T}_{\mathrm{FH}}$ cell subset within a TLO GC may not promote efficient affinity maturation. As demonstrated by the impaired affinity maturation that ensues when $\mathrm{T}$ cell help is artificially augmented (180), $\mathrm{T}_{\mathrm{FH}}$ numbers must be closely controlled in order to maintain a competitive selection advantage for high-affinity variants. Whether this control is achieved within a TLO is not known, and it is perhaps more likely that help will be provided in a disorganized or dysregulated fashion. In support, in a model of tetramethylpecadentane-induced "lipogranulomas," the presence of TLO was associated with, if anything, a reduction in affinity maturation (157). Similarly, loss of control of the $\mathrm{T}_{\mathrm{FH}}$ cell subset within aortic TLOs exacerbates atherosclerosis (145).

Apart from T cell help, canonical GC responses are reliant upon FDCs, which can capture antigen-antibody complexes for presentation to B cells and express chemokines such as CXCL13, which draws $\mathrm{B}$ cells and $\mathrm{T}_{\mathrm{FH}}$ cells to follicles via CXCR5 (243-246). FDCs also provide B cell survival and proliferation factors, such as BAFF (247). The BlyS family of TNF ligands (BAFF and APRIL) and their receptors [BR3 (also termed BAFF-R), TACI, and BCMA] govern survival and differentiation within $B$ cell subsets, which is of particular relevance to humoral alloimmune responses (248). The receptors for BAFF are differentially expressed on B cells at various stages of maturation and activation, and will, thus, likely play a critical role in survival of B cells within TLOs. Thaunat's group has shown that plasma cells which persisted within kidney allografts after administration of rituximab were intimately associated with BAFF secreting cells (249). As BAFF is mainly produced by macrophages, monocytes, and dendritic cells (250), the inflammatory microenvironment could, therefore, provide BAFF-dependent paracrine survival signals to intra-graft $B$ cells in TLOs, as seen in B cell-rich lymphoid follicle-like structures in the meninges of EAE-affected mice where BAFF expression in inflamed tissues is upregulated in chronic relapsing forms of disease (52). Local BAFF could, therefore, provide additional survival signals for B cells within allograft-TLOs and promote tissue-resident humoral alloimmune responses as evidenced by an association between intra-graft BAFF and AMR in kidney transplantation (251), but also could protect autoreactive B cells generated during the (ectopic) GC response from apoptosis (see below) and sustain their differentiation into autoantibody-secreting plasma cells (252).

If not to promote affinity maturation, what role do GCs within TLOs perform? If one assumes that high-affinity mutants are not selected as effectively within a TLO as within a SLO, this implies that irrespective of similarities in clonal constituents at the onset of a response, the output from the SLO and TLO GC responses will increasingly diverge. The $\mathrm{T}_{\mathrm{FH}}$ cell subset is, moreover, critical for ensuring negative selection within the GC-the destruction of potentially autoreactive variants that have arisen from SHM $(253,254)$. For example, in sanroque mutant mice, increased ICOS expression specifically on $\mathrm{T}$ cells results in an aberrant expansion of $\mathrm{T}_{\mathrm{FH}}$ cells and spontaneous GC autoimmunity $(255,256)$. Conventional FoxP3 regulatory CD4 T cells (Tregs), as well as CD8 regulatory $\mathrm{T}$ cells $(257,258)$, are also necessary for prevention of humoral autoimmunity, likely through their inhibitory impact on the $\mathrm{T}_{\mathrm{FH}}$ cell population. Thus, disorders in $\mathrm{T}_{\mathrm{FH}}$ cell function (either intrinsic or through loss of external control) may allow autoreactive B cell variants within the TLO to escape apoptosis and undergo plasma cell differentiation. In this regard, the $\mathrm{T}$ follicular regulatory $\left(\mathrm{T}_{\mathrm{FR}}\right)$ cell subset $(259)$ has yet to be described within TLO. The $\mathrm{T}_{\mathrm{FR}}$ cell subset phenotypically resembles the $\mathrm{T}_{\mathrm{FH}}$ cell subset in surface expression of CXCR5, $\mathrm{PD}-1, \mathrm{ICOS}$, and in positioning within the $\mathrm{B}$ cell follicle, but expresses the master transcription factors (FoxP3 and Bcl-6) for both the Treg and $\mathrm{T}_{\mathrm{FH}}$ cell subsets (260-262). The precise role 
of the $\mathrm{T}_{\mathrm{FR}}$ cell subset is still debated, with recent papers variably suggesting that $\mathrm{T}_{\mathrm{FR}}$ cells are either specific (263) or not specific (264) for target antigen, but their relatively late ingress to the follicle suggests that they do not inhibit development of the GC, and that they either prevent escape of autoimmune variants that arise following SHM (260) or hasten termination of the response (265). This last role may be particularly pertinent to GC activity within TLO, which is characterized by its longevity, and which, consequently, may be more prone to subversion to autoreactivity; either because of failure of negative selection or because of external seeding with newly activated naïve or memory B cells (184, 203, 266, 267).

Aside for disorders in $\mathrm{T}_{\mathrm{FH}}$ cell function, there are several other mechanisms by which the development of autoreactivity is possibly favored within a TLO (see Figure 2). A number of B cell intrinsic pathways have been identified that inhibit development of GC autoimmunity. These include expression of ELL-associated factor 2 (268), and signaling via TLR9 $(269,270)$ or inhibitory FcyRIIB ligand (271-273). Whether these signaling pathways are somehow modulated within a GC
TLO to favor development of autoreactivity is, however, not known. B cell inhibition via FcyRIIB binding is dependent upon immune complexes simultaneously engaging the BCR, and thus local perturbations in effector antibody concentration, or differences in sialylation at the antibody Fc region (274), could conceivably alter the degree of FcyRIIB-mediated inhibition within the TLO. Alternatively, as well as a reservoir for target antigen, the FDC network expresses a variety of cytokines (such as Il-6 and BAFF) and chemokines (CXCL13) thought critical for effective GC function (275). Das et al. have recently reported that, in response to TLR7 signaling, the FDC can also promote autoimmunity, by secreting pro-inflammatory IFN- $\alpha$ (276). Thus, the inflammatory state thought responsible for triggering formation of a peripheral TLO may program an activated FDC phenotype that promotes subsequent diversification of the GC response to encompass autoreactive targets. Heightened cell turnover within the inflammatory milieu of the TLO may additionally increase the likelihood of autoimmunity developing, by overloading the capacity of tangible body macrophages to clear apoptotic bodies within the GC $(277,278)$.

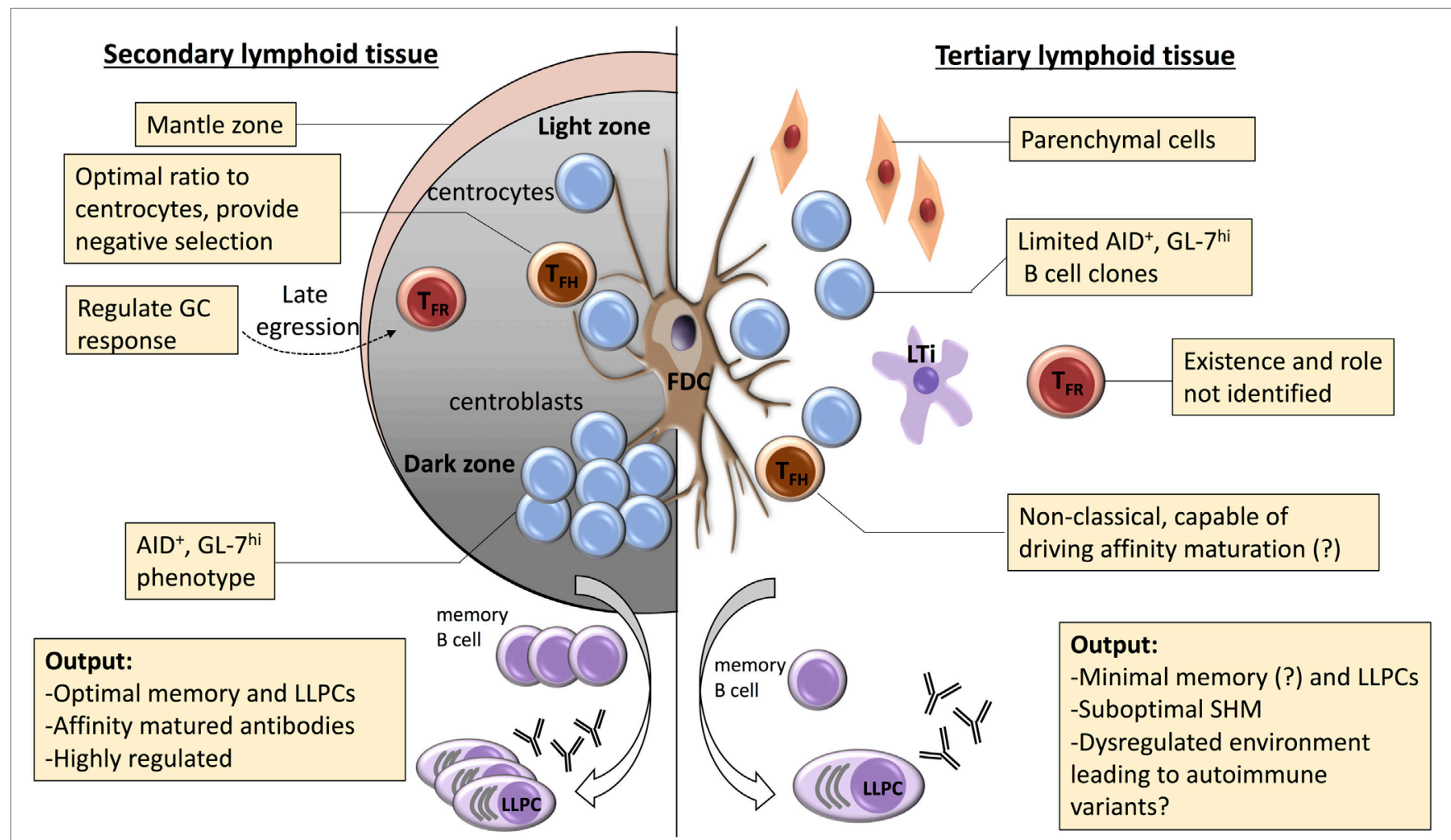

FIGURE 2 | Potential mechanisms for dysregulated selection within tertiary lymphoid organs (TLOs). A number of mechanisms are responsible for regulating the germinal center (GC) response within conventional secondary lymphoid organs. Affinity maturation is critically dependent upon coordinated recycling through the dark zone, with competition for limiting number of $\mathrm{T}$ follicular helper $\left(\mathrm{T}_{\mathrm{FH}}\right)$ cells critical for selection of high-affinity clones. Effective selection is also dependent upon robust processes for destruction of low-affinity clones or those that have mutated to autoreactivity. These are less well understood, but include: optimization of $T_{F H}$ cell numbers; negative input from T follicular regulatory $\left(T_{F R}\right)$ cells; and effective engulfment and disposal by tingible body macrophages. In TLOs, dark/light zone segregation is conspicuously absent, and the role of the $T_{F H}$ cell remains poorly understood. Similarly, the $T_{F R}$ cell population has yet to be characterized. Thus, although GC-type features are frequently described within TLO, it is likely that functional output of these GC-like structures differs from canonical secondary lymphoid function. We propose that the dysregulated nature of the GC response within TLOs favors the escape of autoreactive variants and developing of long-lasting humoral autoimmunity. 


\section{CONCLUSION}

In summary, although components of the B cell GC response are frequently identified within TLOs, the precise function of these putative GCs, and how they compare to GCs within canonical SLOs, has yet to be determined. It seems likely from the expression of $\operatorname{AID}(32,146,147,149,151)$ and from clonal analysis of the constituent B cells (154), that SHM can occur. However, as discussed, we now know that physical segregation of the GC into dark and light zones is crucial for effective SHM, as this enables limiting numbers of $\mathrm{T}_{\mathrm{FH}}$ cells within the light zone to inform the subsequent proliferative response of circling GC B cells in the dark zone. Such readily identifiable dark/light zone configuration is conspicuously absent from reported GCs within TLOs, and when allied to concerns relating to $\mathrm{T}_{\mathrm{FH}}$ cell dysfunction, we propose that it is likely that affinity maturation within a TLO is at best sub-optimal, and certainly not as effective as within canonical lymphoid tissue. This is supported by the limited evidence available (157). Instead, it seems probable that dysregulated or uncoordinated responses within the TLO favor a breakdown of negative selection, with subsequent epitope diversification to encompass autoimmune variants. In this respect, we have previously reported, in a murine model of chronic heart graft rejection, that transplantation of MHC class II mismatched heart grafts triggers long-lasting antinuclear IgG autoantibody responses in the recipient (279) and is associated with development of intra-allograft TLO with prominent $B$ cell features (32). Our recent work has highlighted

\section{REFERENCES}

1. Butcher EC, Picker LJ. Lymphocyte homing and homeostasis. Science (1996) 272(5258):60-6. doi:10.1126/science.272.5258.60

2. Pitzalis C, Jones GW, Bombardieri M, Jones SA. Ectopic lymphoid-like structures in infection, cancer and autoimmunity. Nat Rev Immunol (2014) 14(7):447-62. doi:10.1038/nri3700

3. Carragher DM, Rangel-Moreno J, Randall TD. Ectopic lymphoid tissues and local immunity. Semin Immunol (2008) 20(1):26-42. doi:10.1016/j. smim.2007.12.004

4. Aloisi F, Pujol-Borrell R. Lymphoid neogenesis in chronic inflammatory diseases. Nat Rev Immunol (2006) 6(3):205-17. doi:10.1038/nri1786

5. Dieu-Nosjean MC, Goc J, Giraldo NA, Sautes-Fridman C, Fridman WH. Tertiary lymphoid structures in cancer and beyond. Trends Immunol (2014) 35(11):571-80. doi:10.1016/j.it.2014.09.006

6. Neyt K, Perros F, GeurtsvanKessel CH, Hammad H, Lambrecht BN. Tertiary lymphoid organs in infection and autoimmunity. Trends Immunol (2012) 33(6):297-305. doi:10.1016/j.it.2012.04.006

7. Yoshida H, Naito A, Inoue J, Satoh M, Santee-Cooper SM, Ware CF, et al. Different cytokines induce surface lymphotoxin-alphabeta on IL-7 receptor-alpha cells that differentially engender lymph nodes and Peyer's patches. Immunity (2002) 17(6):823-33. doi:10.1016/S1074-7613(02) 00479-X

8. Randall TD, Carragher DM, Rangel-Moreno J. Development of secondary lymphoid organs. Annu Rev Immunol (2008) 26:627-50. doi:10.1146/ annurev.immunol.26.021607.090257

9. Kim D, Mebius RE, MacMicking JD, Jung S, Cupedo T, Castellanos Y, et al. Regulation of peripheral lymph node genesis by the tumor necrosis factor family member TRANCE. J Exp Med (2000) 192(10):1467-78. doi:10.1084/ jem.192.10.1467

10. Honda K, Nakano H, Yoshida H, Nishikawa S, Rennert P, Ikuta K, et al. Molecular basis for hematopoietic/mesenchymal interaction during that help for the development of humoral autoimmunity is provided by an unusual form of "peptide-degenerate" (but cognate) interaction between recipient autoreactive $\mathrm{B}$ cells and donor $\mathrm{CD} 4 \mathrm{~T}$ cells that are passengers with the heart graft (280). Surprisingly, although triggered by donor CD4 T cell graft-versus-host recognition of MHC class II determinants on recipient B cells, maintenance of splenic and intra-allograft GC activity is dependent upon provision of help from $\mathrm{T}_{\mathrm{FH}}$ differentiation of a recipient $\mathrm{CD} 4 \mathrm{~T}$ cell subset. The chronic GC response that ensues is associated with spreading to encompass autoantibody responses against vimentin protein (281). This model, therefore, provides the opportunity, which our ongoing work will address, to clarify the relationship between aberrant CD4 T cell help and diversification of the TLO humoral autoimmune response to target new, previously quiescent epitopes which have been previously shown to be associated with detrimental graft function (282).

\section{AUTHOR CONTRIBUTIONS}

All authors contributed equally to the design and preparation of this review. JA configured the summary table and figures.

\section{FUNDING}

JA was supported by a grant from King Saud University, Kingdom of Saudi Arabia. RM was supported by a European Society of Organ Transplantation Junior Basic Science Grant.

initiation of Peyer's patch organogenesis. J Exp Med (2001) 193(5):621-30. doi:10.1084/jem.193.5.621

11. Eberl G, Marmon S, Sunshine MJ, Rennert PD, Choi Y, Littman DR. An essential function for the nuclear receptor RORgamma(t) in the generation of fetal lymphoid tissue inducer cells. Nat Immunol (2004) 5(1):64-73. doi:10.1038/ni1022

12. Yokota Y, Mansouri A, Mori S, Sugawara S, Adachi S, Nishikawa S, et al. Development of peripheral lymphoid organs and natural killer cells depends on the helix-loop-helix inhibitor Id2. Nature (1999) 397(6721): 702-6. doi:10.1038/17812

13. Mebius RE. Organogenesis of lymphoid tissues. Nat Rev Immunol (2003) 3(4):292-303. doi:10.1038/nril054

14. van de Pavert SA, Mebius RE. New insights into the development of lymphoid tissues. Nat Rev Immunol (2010) 10(9):664-74. doi:10.1038/nri2832

15. Sun Z, Unutmaz D, Zou YR, Sunshine MJ, Pierani A, Brenner-Morton S, et al. Requirement for RORgamma in thymocyte survival and lymphoid organ development. Science (2000) 288(5475):2369-73. doi:10.1126/science. 288.5475.2369

16. Fukuyama S, Hiroi T, Yokota Y, Rennert PD, Yanagita M, Kinoshita N, et al. Initiation of NALT organogenesis is independent of the IL-7R, LTbetaR, and NIK signaling pathways but requires the Id 2 gene and CD3(-)CD4(+)CD45(+) cells. Immunity (2002) 17(1):31-40. doi:10.1016/ S1074-7613(02)00339-4

17. Mebius RE, Rennert P, Weissman IL. Developing lymph nodes collect CD4+CD3- LTbeta+ cells that can differentiate to APC, NK cells, and follicular cells but not T or B cells. Immunity (1997) 7(4):493-504. doi:10.1016/ S1074-7613(00)80371-4

18. Kim MY, McConnell FM, Gaspal FM, White A, Glanville SH, Bekiaris V, et al. Function of CD4+CD3- cells in relation to B- and T-zone stroma in spleen. Blood (2007) 109(4):1602-10. doi:10.1182/blood-2006-04-018465

19. Kim MY, Toellner KM, White A, McConnell FM, Gaspal FM, Parnell SM, et al. Neonatal and adult CD4+ CD3- cells share similar gene expression 
profile, and neonatal cells up-regulate OX40 ligand in response to TL1A (TNFSF15). J Immunol (2006) 177(5):3074-81. doi:10.4049/jimmunol.177. 5.3074

20. Kim MY, Gaspal FM, Wiggett HE, McConnell FM, Gulbranson-Judge A, Raykundalia C, et al. CD4(+)CD3(-) accessory cells costimulate primed CD4 $\mathrm{T}$ cells through OX40 and CD30 at sites where T cells collaborate with B cells. Immunity (2003) 18(5):643-54. doi:10.1016/S1074-7613(03) 00110-9

21. Lane PJ, Gaspal FM, Kim MY. Two sides of a cellular coin: CD4(+)CD3cells regulate memory responses and lymph-node organization. Nat Rev Immunol (2005) 5(8):655-60. doi:10.1038/nri1665

22. Kim MY, Anderson G, White A, Jenkinson E, Arlt W, Martensson IL, et al. OX40 ligand and CD30 ligand are expressed on adult but not neonatal CD4+CD3- inducer cells: evidence that IL-7 signals regulate CD30 ligand but not OX40 ligand expression. JImmunol (2005) 174(11):6686-91. doi:10.4049/jimmunol.174.11.6686

23. Kim HJ, Kammertoens T, Janke M, Schmetzer O, Qin Z, Berek C, et al. Establishment of early lymphoid organ infrastructure in transplanted tumors mediated by local production of lymphotoxin alpha and in the combined absence of functional B and T cells. J Immunol (2004) 172(7):4037-47. doi:10.4049/jimmunol.172.7.4037

24. Meier D, Bornmann C, Chappaz S, Schmutz S, Otten LA, Ceredig R, et al. Ectopic lymphoid-organ development occurs through interleukin 7-mediated enhanced survival of lymphoid-tissue-inducer cells. Immunity (2007) 26(5):643-54. doi:10.1016/j.immuni.2007.04.009

25. Cupedo T, Jansen W, Kraal G, Mebius RE. Induction of secondary and tertiary lymphoid structures in the skin. Immunity (2004) 21(5):655-67. doi:10.1016/j.immuni.2004.09.006

26. Luther SA, Ansel KM, Cyster JG. Overlapping roles of CXCL13, interleukin 7 receptor alpha, and CCR7 ligands in lymph node development. J Exp Med (2003) 197(9):1191-8. doi:10.1084/jem.20021294

27. Luther SA, Lopez T, Bai W, Hanahan D, Cyster JG. BLC expression in pancreatic islets causes B cell recruitment and lymphotoxin-dependent lymphoid neogenesis. Immunity (2000) 12(5):471-81. doi:10.1016/S10747613(00)80199-5

28. Evans I, Kim MY. Involvement of lymphoid inducer cells in the development of secondary and tertiary lymphoid structure. BMB Rep (2009) 42(4): 189-93. doi:10.5483/BMBRep.2009.42.4.189

29. Lochner M, Ohnmacht C, Presley L, Bruhns P, Si-Tahar M, Sawa S, et al. Microbiota-induced tertiary lymphoid tissues aggravate inflammatory disease in the absence of RORgamma $\mathrm{t}$ and LTi cells. J Exp Med (2011) 208(1):125-34. doi:10.1084/jem.20100052

30. Marinkovic T, Garin A, Yokota Y, Fu YX, Ruddle NH, Furtado GC, et al. Interaction of mature $\mathrm{CD} 3+\mathrm{CD} 4+\mathrm{T}$ cells with dendritic cells triggers the development of tertiary lymphoid structures in the thyroid. JClin Invest (2006) 116:2622-32. doi:10.1172/JCI28993

31. Thaunat O, Patey N, Caligiuri G, Gautreau C, Mamani-Matsuda M, Mekki Y, et al. Chronic rejection triggers the development of an aggressive intragraft immune response through recapitulation of lymphoid organogenesis. J Immunol (2010) 185(1):717-28. doi:10.4049/jimmunol. 0903589

32. Motallebzadeh R, Rehakova S, Conlon TM, Win TS, Callaghan CJ, Goddard M, et al. Blocking lymphotoxin signaling abrogates the development of ectopic lymphoid tissue within cardiac allografts and inhibits effector antibody responses. FASEB J (2012) 26(1):51-62. doi:10.1096/f.11186973

33. Kielczewski JL, Horai R, Jittayasothorn Y, Chan CC, Caspi RR. Tertiary lymphoid tissue forms in retinas of mice with spontaneous autoimmune uveitis and has consequences on visual function. JImmunol (2016) 196(3):1013-25. doi:10.4049/jimmunol.1501570

34. Romme Christensen J, Bornsen L, Ratzer R, Piehl F, Khademi M, Olsson T, et al. Systemic inflammation in progressive multiple sclerosis involves follicular T-helper, Th17- and activated B-cells and correlates with progression. PLoS One (2013) 8(3):e57820. doi:10.1371/journal.pone. 0057820

35. Guedj K, Khallou-Laschet J, Clement M, Morvan M, Gaston AT, Fornasa G, et al. M1 macrophages act as LTbetaR-independent lymphoid tissue inducer cells during atherosclerosis-related lymphoid neogenesis. Cardiovasc Res (2014) 101(3):434-43. doi:10.1093/cvr/cvt263
36. Peters A, Pitcher LA, Sullivan JM, Mitsdoerffer M, Acton SE, Franz B, et al. Th17 cells induce ectopic lymphoid follicles in central nervous system tissue inflammation. Immunity (2011) 35(6):986-96. doi:10.1016/j. immuni.2011.10.015

37. Luther SA, Bidgol A, Hargreaves DC, Schmidt A, Xu Y, Paniyadi J, et al. Differing activities of homeostatic chemokines CCL19, CCL21, and CXCL12 in lymphocyte and dendritic cell recruitment and lymphoid neogenesis. J Immunol (2002) 169(1):424-33. doi:10.4049/jimmunol.169.1.424

38. Huibers MM, Gareau AJ, Vink A, Kruit R, Feringa H, Beerthuijzen JM, et al. The composition of ectopic lymphoid structures suggests involvement of a local immune response in cardiac allograft vasculopathy. J Heart Lung Transplant (2015) 34(5):734-45. doi:10.1016/j.healun.2014. 11.022

39. Motallebzadeh R, Bolton EM, Pettigrew GJ. Lymphoid tissue formation in allografts: innocent until proven guilty. Transplantation (2008) 85(3): 309-11. doi:10.1097/TP.0b013e318162d2d0

40. Thaunat O, Field AC, Dai J, Louedec L, Patey N, Bloch MF, et al. Lymphoid neogenesis in chronic rejection: evidence for a local humoral alloimmune response. Proc Natl Acad Sci U S A (2005) 102(41):14723-8. doi:10.1073/pnas.0507223102

41. Kerjaschki D, Regele HM, Moosberger I, Nagy-Bojarski K, Watschinger B, Soleiman A, et al. Lymphatic neoangiogenesis in human kidney transplants is associated with immunologically active lymphocytic infiltrates. J Am Soc Nephrol (2004) 15(3):603-12. doi:10.1097/01.ASN.0000113316. 52371.2E

42. Sato M, Hirayama S, Hwang DM, Lara-Guerra H, Wagnetz D, Waddell TK, et al. The role of intrapulmonary de novo lymphoid tissue in obliterative bronchiolitis after lung transplantation. J Immunol (2009) 182(11):7307-16. doi:10.4049/jimmunol.0803606

43. Wehner JR, Fox-Talbot K, Halushka MK, Ellis C, Zachary AA, Baldwin WM III. B cells and plasma cells in coronaries of chronically rejected cardiac transplants. Transplantation (2010) 89(9):1141-8. doi:10.1097/TP. 0b013e3181d3f271

44. Koenig A, Thaunat O. Lymphoid neogenesis and tertiary lymphoid organs in transplanted organs. Front Immunol (2016) 7:646. doi:10.3389/fimmu. 2016.00646

45. Baddoura FK, Nasr IW, Wrobel B, Li Q, Ruddle NH, Lakkis FG. Lymphoid neogenesis in murine cardiac allografts undergoing chronic rejection. Am J Transplant (2005) 5(3):510-6. doi:10.1111/j.1600-6143.2004. 00714.x

46. Di Carlo E, D’Antuono T, Contento S, Di Nicola M, Ballone E, Sorrentino C. Quilty effect has the features of lymphoid neogenesis and shares CXCL13CXCR5 pathway with recurrent acute cardiac rejections. Am J Transplant (2007) 7(1):201-10. doi:10.1111/j.1600-6143.2006.01584.x

47. Armengol MP, Juan M, Lucas-Martin A, Fernandez-Figueras MT, Jaraquemada D, Gallart T, et al. Thyroid autoimmune disease: demonstration of thyroid antigen-specific B cells and recombination-activating gene expression in chemokine-containing active intrathyroidal germinal centers. Am J Pathol (2001) 159(3):861-73. doi:10.1016/S0002-9440(10)61762-2

48. Kang YM, Zhang X, Wagner UG, Yang H, Beckenbaugh RD, Kurtin PJ, et al. CD8 $\mathrm{T}$ cells are required for the formation of ectopic germinal centers in rheumatoid synovitis. J Exp Med (2002) 195(10):1325-36. doi:10.1084/ jem.20011565

49. Takemura S, Braun A, Crowson C, Kurtin PJ, Cofield RH, O’Fallon WM, et al. Lymphoid neogenesis in rheumatoid synovitis. JImmunol (2001) 167(2):1072-80. doi:10.4049/jimmunol.167.2.1072

50. Carlsen HS, Baekkevold ES, Johansen FE, Haraldsen G, Brandtzaeg P. B cell attracting chemokine 1 (CXCL13) and its receptor CXCR5 are expressed in normal and aberrant gut associated lymphoid tissue. Gut (2002) 51(3):364-71. doi:10.1136/gut.51.3.364

51. Amft N, Curnow SJ, Scheel-Toellner D, Devadas A, Oates J, Crocker J, et al. Ectopic expression of the B cell-attracting chemokine BCA-1 (CXCL13) on endothelial cells and within lymphoid follicles contributes to the establishment of germinal center-like structures in Sjogren's syndrome. Arthritis Rheum (2001) 44(11):2633-41. doi:10.1002/1529-0131 (200111)44:11<2633::AID-ART443>3.0.CO;2-9

52. Magliozzi R, Columba-Cabezas S, Serafini B, Aloisi F. Intracerebral expression of CXCL13 and BAFF is accompanied by formation of lymphoid follicle-like structures in the meninges of mice with relapsing experimental 
autoimmune encephalomyelitis. J Neuroimmunol (2004) 148(1-2):11-23. doi:10.1016/j.jneuroim.2003.10.056

53. Sarwal M, Chua MS, Kambham N, Hsieh SC, Satterwhite T, Masek M, et al. Molecular heterogeneity in acute renal allograft rejection identified by DNA microarray profiling. N Engl J Med (2003) 349(2):125-38. doi:10.1056/ NEJMoa035588

54. Noorchashm H, Reed AJ, Rostami SY, Mozaffari R, Zekavat G, Koeberlein $\mathrm{B}$, et al. B cell-mediated antigen presentation is required for the pathogenesis of acute cardiac allograft rejection. J Immunol (2006) 177(11):7715-22. doi:10.4049/jimmunol.177.11.7715

55. Krukemeyer MG, Moeller J, Morawietz L, Rudolph B, Neumann U, Theruvath $\mathrm{T}$, et al. Description of $\mathrm{B}$ lymphocytes and plasma cells, complement, and chemokines/receptors in acute liver allograft rejection. Transplantation (2004) 78(1):65-70. doi:10.1097/01.TP.0000132324. 14207.8B

56. Einecke G, Reeve J, Mengel M, Sis B, Bunnag S, Mueller TF, et al. Expression of B cell and immunoglobulin transcripts is a feature of inflammation in late allografts. Am J Transplant (2008) 8(7):1434-43. doi:10.1111/j. 1600-6143.2008.02232.x

57. Lazzeri E, Rotondi M, Mazzinghi B, Lasagni L, Buonamano A, Rosati A, et al. High CXCL10 expression in rejected kidneys and predictive role of pretransplant serum CXCL10 for acute rejection and chronic allograft nephropathy. Transplantation (2005) 79(9):1215-20. doi:10.1097/01. TP.0000160759.85080.2E

58. Steinmetz OM, Panzer U, Kneissler U, Harendza S, Lipp M, Helmchen U, et al. BCA-1/CXCL13 expression is associated with CXCR5-positive B-cell cluster formation in acute renal transplant rejection. Kidney Int (2005) 67(4):1616-21. doi:10.1111/j.1523-1755.2005.00244.x

59. Mayer V, Hudkins KL, Heller F, Schmid H, Kretzler M, Brandt U, et al. Expression of the chemokine receptor CCR1 in human renal allografts. Nephrol Dial Transplant (2007) 22(6):1720-9. doi:10.1093/ndt/ gfm007

60. Lo DJ, Weaver TA, Kleiner DE, Mannon RB, Jacobson LM, Becker BN, et al. Chemokines and their receptors in human renal allotransplantation. Transplantation (2011) 91(1):70-7. doi:10.1097/TP.0b013e3181fe12fc

61. Lu Y, Li B, Shen Q, Wang R, Chen Z, Jiang H, et al. Effects of CD20+ B-cell infiltration into allografts on kidney transplantation outcomes: a systematic review and meta-analysis. Oncotarget (2017) 8(23):37935-41. doi:10.18632/oncotarget.16229

62. Zarkhin V, Kambham N, Li L, Kwok S, Hsieh SC, Salvatierra O, et al. Characterization of intra-graft B cells during renal allograft rejection. Kidney Int (2008) 74(5):664-73. doi:10.1038/ki.2008.249

63. Malynn BA, Romeo DT, Wortis HH. Antigen-specific B cells efficiently present low doses of antigen for induction of $\mathrm{T}$ cell proliferation. J Immunol (1985) 135(2):980-8.

64. Nasr IW, Reel M, Oberbarnscheidt MH, Mounzer RH, Baddoura FK, Ruddle NH, et al. Tertiary lymphoid tissues generate effector and memory T cells that lead to allograft rejection. Am J Transplant (2007) 7(5):1071-9. doi:10.1111/j.1600-6143.2007.01756.x

65. Scheepstra C, Bemelman FJ, van der Loos C, Rowshani AT, van DonselaarVan der Pant KA, Idu MM, et al. B cells in cluster or in a scattered pattern do not correlate with clinical outcome of renal allograft rejection. Transplantation (2008) 86(6):772-8. doi:10.1097/TP.0b013e3181860a74

66. Sze DM, Toellner KM, Garcia de Vinuesa C, Taylor DR, MacLennan IC. Intrinsic constraint on plasmablast growth and extrinsic limits of plasma cell survival. J Exp Med (2000) 192(6):813-21. doi:10.1084/jem. 192.6.813

67. Manz RA, Thiel A, Radbruch A. Lifetime of plasma cells in the bone marrow. Nature (1997) 388(6638):133-4. doi:10.1038/40540

68. Hauser AE, Debes GF, Arce S, Cassese G, Hamann A, Radbruch A, et al. Chemotactic responsiveness toward ligands for CXCR3 and CXCR4 is regulated on plasma blasts during the time course of a memory immune response. J Immunol (2002) 169(3):1277-82. doi:10.4049/jimmunol. 169.3.1277

69. Odendahl M, Mei H, Hoyer BF, Jacobi AM, Hansen A, Muehlinghaus G, et al. Generation of migratory antigen-specific plasma blasts and mobilization of resident plasma cells in a secondary immune response. Blood (2005) 105(4):1614-21. doi:10.1182/blood-2004-07-2507
70. Cassese G, Lindenau S, de Boer B, Arce S, Hauser A, Riemekasten G, et al. Inflamed kidneys of NZB/ W mice are a major site for the homeostasis of plasma cells. Eur J Immunol (2001) 31(9):2726-32. doi:10.1002/ 1521-4141(200109)31:9<2726::AID-IMMU2726>3.0.CO;2-H

71. Grabner R, Lotzer K, Dopping S, Hildner M, Radke D, Beer M, et al. Lymphotoxin beta receptor signaling promotes tertiary lymphoid organogenesis in the aorta adventitia of aged ApoE-/- mice. J Exp Med (2009) 206(1):233-48. doi:10.1084/jem.20080752

72. Kratz A, Campos-Neto A, Hanson MS, Ruddle NH. Chronic inflammation caused by lymphotoxin is lymphoid neogenesis. J Exp Med (1996) 183(4):1461-72. doi:10.1084/jem.183.4.1461

73. Ansel KM, Ngo VN, Hyman PL, Luther SA, Forster R, Sedgwick JD, et al. A chemokine-driven positive feedback loop organizes lymphoid follicles. Nature (2000) 406(6793):309-14. doi:10.1038/35018581

74. McDonald KG, McDonough JS, Newberry RD. Adaptive immune responses are dispensable for isolated lymphoid follicle formation: antigen-naive, lymphotoxin-sufficient B lymphocytes drive the formation of mature isolated lymphoid follicles. J Immunol (2005) 174(9):5720-8. doi:10.4049/ jimmunol.174.9.5720

75. Ngo VN, Korner H, Gunn MD, Schmidt KN, Riminton DS, Cooper MD, et al. Lymphotoxin alpha/beta and tumor necrosis factor are required for stromal cell expression of homing chemokines in B and T cell areas of the spleen. J Exp Med (1999) 189(2):403-12. doi:10.1084/jem.189.2.403

76. Endres R, Alimzhanov MB, Plitz T, Futterer A, Kosco-Vilbois MH, Nedospasov SA, et al. Mature follicular dendritic cell networks depend on expression of lymphotoxin beta receptor by radioresistant stromal cells and of lymphotoxin beta and tumor necrosis factor by B cells. J Exp Med (1999) 189(1):159-68. doi:10.1084/jem.189.1.159

77. Gonzalez M, Mackay F, Browning JL, Kosco-Vilbois MH, Noelle RJ. The sequential role of lymphotoxin and B cells in the development of splenic follicles. J Exp Med (1998) 187(7):997-1007. doi:10.1084/jem.187. 7.997

78. Pokholok DK, Maroulakou IG, Kuprash DV, Alimzhanov MB, Kozlov SV, Novobrantseva TI, et al. Cloning and expression analysis of the murine lymphotoxin beta gene. Proc Natl Acad Sci U S A (1995) 92(3):674-8. doi:10.1073/pnas.92.3.674

79. Worm M, Geha RS. CD40 ligation induces lymphotoxin alpha gene expression in human B cells. Int Immunol (1994) 6(12):1883-90. doi:10.1093/ intimm/6.12.1883

80. Browning JL, Dougas I, Ngam-ek A, Bourdon PR, Ehrenfels BN, Miatkowski K, et al. Characterization of surface lymphotoxin forms. Use of specific monoclonal antibodies and soluble receptors. J Immunol (1995) 154(1):33-46.

81. Millet I, Ruddle NH. Differential regulation of lymphotoxin (LT), lymphotoxin-beta (LT-beta), and TNF-alpha in murine T cell clones activated through the TCR. J Immunol (1994) 152(9):4336-46.

82. Tumanov A, Kuprash D, Lagarkova M, Grivennikov S, Abe K, Shakhov A, et al. Distinct role of surface lymphotoxin expressed by B cells in the organization of secondary lymphoid tissues. Immunity (2002) 17(3):239-50. doi:10.1016/S1074-7613(02)00397-7

83. Cyster JG. Chemokines and cell migration in secondary lymphoid organs. Science (1999) 286(5447):2098-102. doi:10.1126/science.286.5447.2098

84. Girard JP, Springer TA. High endothelial venules (HEVs): specialized endothelium for lymphocyte migration. Immunol Today (1995) 16(9): 449-57. doi:10.1016/0167-5699(95)80023-9

85. Marelli-Berg FM, Cannella L, Dazzi F, Mirenda V. The highway code of T cell trafficking. J Pathol (2008) 214(2):179-89. doi:10.1002/path.2269

86. Rot A, von Andrian UH. Chemokines in innate and adaptive host defense: basic chemokinese grammar for immune cells. Annu Rev Immunol (2004) 22:891-928. doi:10.1146/annurev.immunol.22.012703. 104543

87. Streeter PR, Rouse BT, Butcher EC. Immunohistologic and functional characterization of a vascular addressin involved in lymphocyte homing into peripheral lymph nodes. J Cell Biol (1988) 107(5):1853-62. doi:10.1083/ jcb.107.5.1853

88. Ruddle NH. High endothelial venules and lymphatic vessels in tertiary lymphoid organs: characteristics, functions, and regulation. Front Immunol (2016) 7:491. doi:10.3389/fimmu.2016.00491 
89. Sallusto F, Lenig D, Forster R, Lipp M, Lanzavecchia A. Two subsets of memory $\mathrm{T}$ lymphocytes with distinct homing potentials and effector functions. Nature (1999) 401(6754):708-12. doi:10.1038/44385

90. Dubey LK, Lebon L, Mosconi I, Yang CY, Scandella E, Ludewig B, et al. Lymphotoxin-dependent B cell-FRC crosstalk promotes de novo follicle formation and antibody production following intestinal helminth infection. Cell Rep (2016) 15(7):1527-41. doi:10.1016/j.celrep.2016. 04.023

91. Bajenoff M, Egen JG, Koo LY, Laugier JP, Brau F, Glaichenhaus N, et al. Stromal cell networks regulate lymphocyte entry, migration, and territoriality in lymph nodes. Immunity (2006) 25(6):989-1001. doi:10.1016/j. immuni.2006.10.011

92. Nolte MA, Belien JA, Schadee-Eestermans I, Jansen W, Unger WW, van Rooijen N, et al. A conduit system distributes chemokines and small blood-borne molecules through the splenic white pulp. J Exp Med (2003) 198(3):505-12. doi:10.1084/jem.20021801

93. Sixt M, Kanazawa N, Selg M, Samson T, Roos G, Reinhardt DP, et al. The conduit system transports soluble antigens from the afferent lymph to resident dendritic cells in the $\mathrm{T}$ cell area of the lymph node. Immunity (2005) 22(1):19-29. doi:10.1016/j.immuni.2004.11.013

94. Link A, Vogt TK, Favre S, Britschgi MR, Acha-Orbea H, Hinz B, et al. Fibroblastic reticular cells in lymph nodes regulate the homeostasis of naive T cells. Nat Immunol (2007) 8(11):1255-65. doi:10.1038/ ni1513

95. Lee JW, Epardaud M, Sun J, Becker JE, Cheng AC, Yonekura AR, et al. Peripheral antigen display by lymph node stroma promotes $\mathrm{T}$ cell tolerance to intestinal self. Nat Immunol (2007) 8(2):181-90. doi:10.1038/ni1427

96. Svensson M, Maroof A, Ato M, Kaye PM. Stromal cells direct local differentiation of regulatory dendritic cells. Immunity (2004) 21(6):805-16. doi:10.1016/j.immuni.2004.10.012

97. Canete JD, Celis R, Yeremenko N, Sanmarti R, van Duivenvoorde L, Ramirez J, et al. Ectopic lymphoid neogenesis is strongly associated with activation of the IL-23 pathway in rheumatoid synovitis. Arthritis Res Ther (2015) 17:173. doi:10.1186/s13075-015-0688-0

98. Ciccia F, Guggino G, Rizzo A, Ferrante A, Raimondo S, Giardina A, et al. Potential involvement of IL-22 and IL-22-producing cells in the inflamed salivary glands of patients with Sjogren's syndrome. Ann Rheum Dis (2012) 71(2):295-301. doi:10.1136/ard.2011.154013

99. Barone F, Nayar S, Campos J, Cloake T, Withers DR, Toellner KM, et al. IL-22 regulates lymphoid chemokine production and assembly of tertiary lymphoid organs. Proc Natl Acad Sci U S A (2015) 112(35):11024-9. doi:10.1073/pnas.1503315112

100. Jones GW, Bombardieri M, Greenhill CJ, McLeod L, Nerviani A, Rocher-Ros V, et al. Interleukin-27 inhibits ectopic lymphoid-like structure development in early inflammatory arthritis. J Exp Med (2015) 212(11):1793-802. doi:10.1084/jem.20132307

101. Langrish CL, Chen Y, Blumenschein WM, Mattson J, Basham B, Sedgwick JD, et al. IL-23 drives a pathogenic T cell population that induces autoimmune inflammation. J Exp Med (2005) 201(2):233-40. doi:10.1084/ jem.20041257

102. Esen N, Rainey-Barger EK, Huber AK, Blakely PK, Irani DN. Type-I interferons suppress microglial production of the lymphoid chemokine, CXCL13. Glia (2014) 62(9):1452-62. doi:10.1002/glia.22692

103. Rangel-Moreno J, Carragher DM, de la Luz Garcia-Hernandez M, Hwang JY, Kusser K, Hartson L, et al. The development of inducible bronchus-associated lymphoid tissue depends on IL-17. Nat Immunol (2011) 12(7):639-46. doi:10.1038/ni.2053

104. Klimiuk PA, Sierakowski S, Latosiewicz R, Cylwik JP, Cylwik B, Skowronski J, et al. Circulating tumour necrosis factor alpha and soluble tumour necrosis factor receptors in patients with different patterns of rheumatoid synovitis. Ann Rheum Dis (2003) 62(5):472-5. doi:10.1136/ ard.62.5.472

105. Pikor NB, Astarita JL, Summers-Deluca L, Galicia G, Qu J, Ward LA, et al. Integration of Th17- and lymphotoxin-derived signals initiates meningeal-resident stromal cell remodeling to propagate neuroinflammation. Immunity (2015) 43(6):1160-73. doi:10.1016/j.immuni.2015.11.010

106. Burlingham WJ, Love RB, Jankowska-Gan E, Haynes LD, Xu Q, Bobadilla JL, et al. IL-17-dependent cellular immunity to collagen type V predisposes to obliterative bronchiolitis in human lung transplants. J Clin Invest (2007) 117(11):3498-506. doi:10.1172/JCI28031

107. Deteix C, Attuil-Audenis V, Duthey A, Patey N, McGregor B, Dubois V, et al. Intragraft Th17 infiltrate promotes lymphoid neogenesis and hastens clinical chronic rejection. J Immunol (2010) 184(9):5344-51. doi:10.4049/ jimmunol.0902999

108. Korn T, Bettelli E, Oukka M, Kuchroo VK. IL-17 and Th17 cells. Annu Rev Immunol (2009) 27:485-517. doi:10.1146/annurev.immunol.021908. 132710

109. Vogelzang A, McGuire HM, Yu D, Sprent J, Mackay CR, King C. A fundamental role for interleukin-21 in the generation of $\mathrm{T}$ follicular helper cells. Immunity (2008) 29(1):127-37. doi:10.1016/j.immuni.2008. 06.001

110. Ettinger R, Kuchen S, Lipsky PE. The role of IL-21 in regulating B-cell function in health and disease. Immunol Rev (2008) 223:60-86. doi:10.1111/j. 1600-065X.2008.00631.x

111. Hughes CE, Benson RA, Bedaj M, Maffia P. Antigen-presenting cells and antigen presentation in tertiary lymphoid organs. Front Immunol (2016) 7:481. doi:10.3389/fimmu.2016.00481

112. Carlsen HS, Baekkevold ES, Morton HC, Haraldsen G, Brandtzaeg P. Monocyte-like and mature macrophages produce CXCL13 (B cell-attracting chemokine 1) in inflammatory lesions with lymphoid neogenesis. Blood (2004) 104(10):3021-7. doi:10.1182/blood-2004-02-0701

113. Berry GJ, Burke MM, Andersen C, Bruneval P, Fedrigo M, Fishbein MC, et al. The 2013 International Society for Heart and Lung Transplantation working formulation for the standardization of nomenclature in the pathologic diagnosis of antibody-mediated rejection in heart transplantation. J Heart Lung Transplant (2013) 32(12):1147-62. doi:10.1016/j.healun.2013. 08.011

114. Haas M, Sis B, Racusen LC, Solez K, Glotz D, Colvin RB, et al. Banff 2013 meeting report: inclusion of c4d-negative antibody-mediated rejection and antibody-associated arterial lesions. Am J Transplant (2014) 14(2): 272-83. doi:10.1111/ajt.12590

115. Hueso M, Navarro E, Moreso F, O’Valle F, Perez-Riba M, Del Moral RG, et al. Intragraft expression of the IL-10 gene is up-regulated in renal protocol biopsies with early interstitial fibrosis, tubular atrophy, and subclinical rejection. Am J Pathol (2010) 176(4):1696-704. doi:10.2353/ajpath.2010. 090411

116. Pilmore HL, Painter DM, Bishop GA, McCaughan GW, Eris JM. Early upregulation of macrophages and myofibroblasts: a new marker for development of chronic renal allograft rejection. Transplantation (2000) 69(12): 2658-62. doi:10.1097/00007890-200006270-00028

117. Papadimitriou JC, Drachenberg CB, Munivenkatappa R, Ramos E, Nogueira J, Sailey C, et al. Glomerular inflammation in renal allografts biopsies after the first year: cell types and relationship with antibodymediated rejection and graft outcome. Transplantation (2010) 90(12): 1478-85. doi:10.1097/TP.0b013e3181ff87f5

118. Alitalo K, Carmeliet P. Molecular mechanisms of lymphangiogenesis in health and disease. Cancer Cell (2002) 1(3):219-27. doi:10.1016/S15356108(02)00051-X

119. Maruyama K, Ii M, Cursiefen C, Jackson DG, Keino H, Tomita M, et al. Inflammation-induced lymphangiogenesis in the cornea arises from CD11b-positive macrophages. J Clin Invest (2005) 115(9):2363-72. doi:10.1172/JCI23874

120. Katakai T, Hara T, Sugai M, Gonda H, Shimizu A. Lymph node fibroblastic reticular cells construct the stromal reticulum via contact with lymphocytes. J Exp Med (2004) 200(6):783-95. doi:10.1084/jem.20040254

121. Mueller SN, Germain RN. Stromal cell contributions to the homeostasis and functionality of the immune system. Nat Rev Immunol (2009) 9(9): 618-29. doi:10.1038/nri2588

122. Okuda M, Togawa A, Wada H, Nishikawa S. Distinct activities of stromal cells involved in the organogenesis of lymph nodes and Peyer's patches. J Immunol (2007) 179(2):804-11. doi:10.4049/jimmunol.179.2.804

123. Parsonage G, Filer AD, Haworth O, Nash GB, Rainger GE, Salmon M, et al. A stromal address code defined by fibroblasts. Trends Immunol (2005) 26(3):150-6. doi:10.1016/j.it.2004.11.014

124. Manzo A, Bugatti S, Caporali R, Prevo R, Jackson DG, Uguccioni M, et al. CCL21 expression pattern of human secondary lymphoid organ stroma 
is conserved in inflammatory lesions with lymphoid neogenesis. Am J Pathol (2007) 171(5):1549-62. doi:10.2353/ajpath.2007.061275

125. Sato M, Hirayama S, Matsuda Y, Wagnetz D, Hwang DM, Guan Z, et al. Stromal activation and formation of lymphoid-like stroma in chronic lung allograft dysfunction. Transplantation (2011) 91(12):1398-405. doi:10.1097/TP.0b013e31821b2f7a

126. Peduto L, Dulauroy S, Lochner M, Spath GF, Morales MA, Cumano A, et al. Inflammation recapitulates the ontogeny of lymphoid stromal cells. J Immunol (2009) 182(9):5789-99. doi:10.4049/jimmunol.0803974

127. Barone F, Gardner DH, Nayar S, Steinthal N, Buckley CD, Luther SA. Stromal fibroblasts in tertiary lymphoid structures: a novel target in chronic inflammation. Front Immunol (2016) 7:477. doi:10.3389/fimmu.2016. 00477

128. Buckley CD, Barone F, Nayar S, Benezech C, Caamano J. Stromal cells in chronic inflammation and tertiary lymphoid organ formation. Annu Rev Immunol (2015) 33:715-45. doi:10.1146/annurev-immunol-032713120252

129. Braun A, Takemura S, Vallejo AN, Goronzy JJ, Weyand CM. Lymphotoxin beta-mediated stimulation of synoviocytes in rheumatoid arthritis. Arthritis Rheum (2004) 50(7):2140-50. doi:10.1002/art.20356

130. Bombardieri M, Kam NW, Brentano F, Choi K, Filer A, Kyburz D, et al. A BAFF/APRIL-dependent TLR3-stimulated pathway enhances the capacity of rheumatoid synovial fibroblasts to induce AID expression and Ig class-switching in B cells. Ann Rheum Dis (2011) 70(10):1857-65. doi:10.1136/ard.2011.150219

131. Phillips RJ, Burdick MD, Hong K, Lutz MA, Murray LA, Xue YY, et al. Circulating fibrocytes traffic to the lungs in response to CXCL12 and mediate fibrosis. JClin Invest (2004) 114(3):438-46. doi:10.1172/ JCI200420997

132. Eto D, Lao C, DiToro D, Barnett B, Escobar TC, Kageyama R, et al. IL-21 and IL-6 are critical for different aspects of B cell immunity and redundantly induce optimal follicular helper $\mathrm{CD} 4 \mathrm{~T}$ cell (Th) differentiation. PLoS One (2011) 6(3):e17739. doi:10.1371/journal.pone.0017739

133. Abe J, Shichino $S$, Ueha $S$, Hashimoto $S$, Tomura $M$, Inagaki $Y$, et al. Lymph node stromal cells negatively regulate antigen-specific CD4+ T cell responses. J Immunol (2014) 193(4):1636-44. doi:10.4049/jimmunol. 1302946

134. Ager A. High endothelial venules and other blood vessels: critical regulators of lymphoid organ development and function. Front Immunol (2017) 8:45. doi:10.3389/fimmu.2017.00045

135. Hjelmstrom P, Fjell J, Nakagawa T, Sacca R, Cuff CA, Ruddle NH. Lymphoid tissue homing chemokines are expressed in chronic inflammation. Am J Pathol (2000) 156(4):1133-8. doi:10.1016/S0002-9440(10) 64981-4

136. Drayton DL, Ying X, Lee J, Lesslauer W, Ruddle NH. Ectopic LT alpha beta directs lymphoid organ neogenesis with concomitant expression of peripheral node addressin and a HEV-restricted sulfotransferase. J Exp Med (2003) 197(9):1153-63. doi:10.1084/jem.20021761

137. Bentley KL, Stranford S, Liao S, Mounzer RM, Ruddle FH, Ruddle NH. High endothelial venule reporter mice to probe regulation of lymph node vasculature. Adv Exp Med Biol (2011) 691:35-44. doi:10.1007/978-1-44196612-4_4

138. Truman LA, Bentley KL, Smith EC, Massaro SA, Gonzalez DG, Haberman AM, et al. ProxTom lymphatic vessel reporter mice reveal Prox1 expression in the adrenal medulla, megakaryocytes, and platelets. Am J Pathol (2012) 180(4):1715-25. doi:10.1016/j.ajpath.2011.12.026

139. Futterer A, Mink K, Luz A, Kosco-Vilbois MH, Pfeffer K. The lymphotoxin beta receptor controls organogenesis and affinity maturation in peripheral lymphoid tissues. Immunity (1998) 9(1):59-70. doi:10.1016/S10747613(00)80588-9

140. Denton AE, Roberts EW, Linterman MA, Fearon DT. Fibroblastic reticular cells of the lymph node are required for retention of resting but not activated CD8+ T cells. Proc Natl Acad Sci U S A (2014) 111(33):12139-44. doi:10.1073/pnas.1412910111

141. Cremasco V, Woodruff MC, Onder L, Cupovic J, Nieves-Bonilla JM, Schildberg FA, et al. B cell homeostasis and follicle confines are governed by fibroblastic reticular cells. Nat Immunol (2014) 15(10):973-81. doi:10.1038/ ni. 2965
142. Laskov R, Lancz G, Ruddle NH, McGrath KM, Specter S, Klein T, et al. Production of tumor necrosis factor (TNF-alpha) and lymphotoxin (TNF-beta) by murine pre-B and B cell lymphomas. JImmunol (1990) 144(9):3424-30.

143. Lorenz RG, Chaplin DD, McDonald KG, McDonough JS, Newberry RD. Isolated lymphoid follicle formation is inducible and dependent upon lymphotoxin-sufficient B lymphocytes, lymphotoxin beta receptor, and TNF receptor I function. J Immunol (2003) 170(11):5475-82. doi:10.4049/ jimmunol.170.11.5475

144. Suan D, Sundling C, Brink R. Plasma cell and memory B cell differentiation from the germinal center. Curr Opin Immunol (2017) 45:97-102. doi:10.1016/j.coi.2017.03.006

145. Clement M, Guedj K, Andreata F, Morvan M, Bey L, Khallou-Laschet J, et al. Control of the T follicular helper-germinal center B-cell axis by CD8(+) regulatory $\mathrm{T}$ cells limits atherosclerosis and tertiary lymphoid organ development. Circulation (2015) 131(6):560-70. doi:10.1161/CIRCULATIONAHA. 114.010988

146. Vu Van D, Beier KC, Pietzke LJ, Al Baz MS, Feist RK, Gurka S, et al. Local T/B cooperation in inflamed tissues is supported by $\mathrm{T}$ follicular helper-like cells. Nat Commun (2016) 7:10875. doi:10.1038/ncomms10875

147. Germain C, Gnjatic S, Tamzalit F, Knockaert S, Remark R, Goc J, et al. Presence of $\mathrm{B}$ cells in tertiary lymphoid structures is associated with a protective immunity in patients with lung cancer. Am J Respir Crit Care Med (2014) 189(7):832-44. doi:10.1164/rccm.201309-1611OC

148. Slight SR, Rangel-Moreno J, Gopal R, Lin Y, Fallert Junecko BA, Mehra S, et al. CXCR5(+) Thelper cells mediate protective immunity against tuberculosis. J Clin Invest (2013) 123(2):712-26. doi:10.1172/JCI65728

149. Bombardieri M, Barone F, Lucchesi D, Nayar S, van den Berg WB, Proctor G, et al. Inducible tertiary lymphoid structures, autoimmunity, and exocrine dysfunction in a novel model of salivary gland inflammation in C57BL/6 mice. J Immunol (2012) 189(7):3767-76. doi:10.4049/jimmunol. 1201216

150. Gu-Trantien C, Loi S, Garaud S, Equeter C, Libin M, de Wind A, et al. CD4(+) follicular helper T cell infiltration predicts breast cancer survival. J Clin Invest (2013) 123(7):2873-92. doi:10.1172/JCI67428

151. Nacionales DC, Weinstein JS, Yan XJ, Albesiano E, Lee PY, KellyScumpia KM, et al. B cell proliferation, somatic hypermutation, class switch recombination, and autoantibody production in ectopic lymphoid tissue in murine lupus. JImmunol (2009) 182(7):4226-36. doi:10.4049/ jimmunol.0800771

152. Cheng J, Torkamani A, Grover RK, Jones TM, Ruiz DI, Schork NJ, et al. Ectopic B-cell clusters that infiltrate transplanted human kidneys are clonal. Proc Natl Acad Sci U S A (2011) 108(14):5560-5. doi:10.1073/pnas. 1101148108

153. Scheel T, Gursche A, Zacher J, Haupl T, Berek C. V-region gene analysis of locally defined synovial B and plasma cells reveals selected B cell expansion and accumulation of plasma cell clones in rheumatoid arthritis. Arthritis Rheum (2011) 63(1):63-72. doi:10.1002/art.27767

154. Stott DI, Hiepe F, Hummel M, Steinhauser G, Berek C. Antigen-driven clonal proliferation of B cells within the target tissue of an autoimmune disease. The salivary glands of patients with Sjogren's syndrome. J Clin Invest (1998) 102(5):938-46. doi:10.1172/JCI3234

155. Grewal JS, Pilgrim MJ, Grewal S, Kasman L, Werner P, Bruorton ME, et al. Salivary glands act as mucosal inductive sites via the formation of ectopic germinal centers after site-restricted MCMV infection. FASEB $J$ (2011) 25(5):1680-96. doi:10.1096/fj.10-174656

156. Corsiero E, Bombardieri M, Carlotti E, Pratesi F, Robinson W, Migliorini P, et al. Single cell cloning and recombinant monoclonal antibodies generation from RA synovial B cells reveal frequent targeting of citrullinated histones of NETs. Ann Rheum Dis (2016) 75(10):1866-75. doi:10.1136/ annrheumdis-2015-208356

157. Weinstein JS, Nacionales DC, Lee PY, Kelly-Scumpia KM, Yan XJ, Scumpia PO, et al. Colocalization of antigen-specific B and $\mathrm{T}$ cells within ectopic lymphoid tissue following immunization with exogenous antigen. J Immunol (2008) 181(5):3259-67. doi:10.4049/jimmunol.181. 5.3259

158. Mesin L, Ersching J, Victora GD. Germinal center B cell dynamics. Immunity (2016) 45(3):471-82. doi:10.1016/j.immuni.2016.09.001 
159. Bannard O, Cyster JG. Germinal centers: programmed for affinity maturation and antibody diversification. Curr Opin Immunol (2017) 45:21-30. doi:10.1016/j.coi.2016.12.004

160. Zhang Y, Garcia-Ibanez L, Toellner KM. Regulation of germinal center B-cell differentiation. Immunol Rev (2016) 270(1):8-19. doi:10.1111/imr. 12396

161. Corcoran LM, Tarlinton DM. Regulation of germinal center responses, memory B cells and plasma cell formation-an update. Curr Opin Immunol (2016) 39:59-67. doi:10.1016/j.coi.2015.12.008

162. Victora GD, Nussenzweig MC. Germinal centers. Annu Rev Immunol (2012) 30:429-57. doi:10.1146/annurev-immunol-020711-075032

163. Shlomchik MJ, Weisel F. Germinal centers. Immunol Rev (2012) 247(1): 5-10. doi:10.1111/j.1600-065X.2012.01125.x

164. Garside P, Ingulli E, Merica RR, Johnson JG, Noelle RJ, Jenkins MK. Visualization of specific B and T lymphocyte interactions in the lymph node. Science (1998) 281(5373):96-9. doi:10.1126/science.281.5373.96

165. Kerfoot SM, Yaari G, Patel JR, Johnson KL, Gonzalez DG, Kleinstein SH, et al. Germinal center B cell and T follicular helper cell development initiates in the interfollicular zone. Immunity (2011) 34(6):947-60. doi:10.1016/j. immuni.2011.03.024

166. Reif K, Ekland EH, Ohl L, Nakano H, Lipp M, Forster R, et al. Balanced responsiveness to chemoattractants from adjacent zones determines B-cell position. Nature (2002) 416(6876):94-9. doi:10.1038/416094a

167. MacLennan IC, Toellner KM, Cunningham AF, Serre K, Sze DM, Zuniga E, et al. Extrafollicular antibody responses. Immunol Rev (2003) 194:8-18. doi:10.1034/j.1600-065X.2003.00058.x

168. Jacob J, Kassir R, Kelsoe G. In situ studies of the primary immune response to (4-hydroxy-3-nitrophenyl)acetyl. I. The architecture and dynamics of responding cell populations. J Exp Med (1991) 173(5):1165-75. doi:10.1084/ jem.173.5.1165

169. Gatto D, Paus D, Basten A, Mackay CR, Brink R. Guidance of B cells by the orphan $G$ protein-coupled receptor EBI2 shapes humoral immune responses. Immunity (2009) 31(2):259-69. doi:10.1016/j.immuni.2009.06.016

170. Pereira JP, Kelly LM, Xu Y, Cyster JG. EBI2 mediates B cell segregation between the outer and centre follicle. Nature (2009) 460(7259):1122-6. doi:10.1038/nature08226

171. Green JA, Suzuki K, Cho B, Willison LD, Palmer D, Allen CD, et al. The sphingosine 1-phosphate receptor $\operatorname{S1P}(2)$ maintains the homeostasis of germinal center B cells and promotes niche confinement. Nat Immunol (2011) 12(7):672-80. doi:10.1038/ni.2047

172. Moriyama S, Takahashi N, Green JA, Hori S, Kubo M, Cyster JG, et al. Sphingosine-1-phosphate receptor 2 is critical for follicular helper T cell retention in germinal centers. J Exp Med (2014) 211(7):1297-305. doi:10.1084/jem.20131666

173. Schwickert TA, Victora GD, Fooksman DR, Kamphorst AO, Mugnier MR, Gitlin AD, et al. A dynamic T cell-limited checkpoint regulates affinitydependent B cell entry into the germinal center. J Exp Med (2011) 208(6): 1243-52. doi:10.1084/jem.20102477

174. Paus D, Phan TG, Chan TD, Gardam S, Basten A, Brink R. Antigen recognition strength regulates the choice between extrafollicular plasma cell and germinal center B cell differentiation. J Exp Med (2006) 203(4): 1081-91. doi:10.1084/jem.20060087

175. Scheid JF, Mouquet H, Feldhahn N, Seaman MS, Velinzon K, Pietzsch J, et al. Broad diversity of neutralizing antibodies isolated from memory B cells in HIV-infected individuals. Nature (2009) 458(7238):636-40. doi:10.1038/ nature 07930

176. Kuraoka M, Schmidt AG, Nojima T, Feng F, Watanabe A, Kitamura D, et al. Complex antigens drive permissive clonal selection in germinal centers. Immunity (2016) 44(3):542-52. doi:10.1016/j.immuni.2016.02.010

177. Tas JM, Mesin L, Pasqual G, Targ S, Jacobsen JT, Mano YM, et al. Visualizing antibody affinity maturation in germinal centers. Science (2016) 351(6277):1048-54. doi:10.1126/science.aad3439

178. Rohlich K. Beitrag zur Cytologie der Keimzentren der Lymphknoten. Z Mikrosk Anat Forsch (1930) 20:287-97.

179. Bannard O, Horton RM, Allen CD, An J, Nagasawa T, Cyster JG. Germinal center centroblasts transition to a centrocyte phenotype according to a timed program and depend on the dark zone for effective selection. Immunity (2013) 39(5):912-24. doi:10.1016/j.immuni.2013.08.038
180. Victora GD, Schwickert TA, Fooksman DR, Kamphorst AO, MeyerHermann M, Dustin ML, et al. Germinal center dynamics revealed by multiphoton microscopy with a photoactivatable fluorescent reporter. Cell (2010) 143(4):592-605. doi:10.1016/j.cell.2010.10.032

181. Allen CD, Ansel KM, Low C, Lesley R, Tamamura H, Fujii N, et al. Germinal center dark and light zone organization is mediated by CXCR4 and CXCR5. Nat Immunol (2004) 5(9):943-52. doi:10.1038/ni1100

182. Gitlin AD, Mayer CT, Oliveira TY, Shulman Z, Jones MJ, Koren A, et al. Humoral immunity. $T$ cell help controls the speed of the cell cycle in germinal center B cells. Science (2015) 349(6248):643-6. doi:10.1126/science. aac4919

183. Gitlin AD, Shulman Z, Nussenzweig MC. Clonal selection in the germinal centre by regulated proliferation and hypermutation. Nature (2014) 509(7502):637-40. doi:10.1038/nature 13300

184. McHeyzer-Williams LJ, Milpied PJ, Okitsu SL, McHeyzer-Williams MG. Class-switched memory B cells remodel BCRs within secondary germinal centers. Nat Immunol (2015) 16(3):296-305. doi:10.1038/ni.3095

185. Bannard O, McGowan SJ, Ersching J, Ishido S, Victora GD, Shin JS, et al. Ubiquitin-mediated fluctuations in MHC class II facilitate efficient germinal center B cell responses. J Exp Med (2016) 213(6):993-1009. doi:10.1084/ jem.20151682

186. Vinuesa CG, Linterman MA, Yu D, MacLennan IC. Follicular helper T cells. Annu Rev Immunol (2016) 34:335-68. doi:10.1146/annurev-immunol041015-055605

187. Crotty S. A brief history of T cell help to B cells. Nat Rev Immunol (2015) 15(3):185-9. doi:10.1038/nri3803

188. Li J, Lu E, Yi T, Cyster JG. EBI2 augments Tfh cell fate by promoting interaction with IL-2-quenching dendritic cells. Nature (2016) 533(7601): 110-4. doi:10.1038/nature17947

189. Poholek AC, Hansen K, Hernandez SG, Eto D, Chandele A, Weinstein JS, et al. In vivo regulation of $\mathrm{Bcl} 6$ and $\mathrm{T}$ follicular helper cell development. J Immunol (2010) 185(1):313-26. doi:10.4049/jimmunol.0904023

190. Yu D, Rao S, Tsai LM, Lee SK, He Y, Sutcliffe EL, et al. The transcriptional repressor Bcl-6 directs $\mathrm{T}$ follicular helper cell lineage commitment. Immunity (2009) 31(3):457-68. doi:10.1016/j.immuni.2009.07.002

191. Johnston RJ, Poholek AC, DiToro D, Yusuf I, Eto D, Barnett B, et al. Bcl6 and Blimp-1 are reciprocal and antagonistic regulators of $\mathrm{T}$ follicular helper cell differentiation. Science (2009) 325(5943):1006-10. doi:10.1126/ science. 1175870

192. Nurieva RI, Chung Y, Hwang D, Yang XO, Kang HS, Ma L, et al. Generation of $\mathrm{T}$ follicular helper cells is mediated by interleukin-21 but independent of T helper 1, 2, or 17 cell lineages. Immunity (2008) 29(1):138-49. doi:10.1016/j.immuni.2008.05.009

193. Stuber E, Strober W. The T cell-B cell interaction via OX40-OX40L is necessary for the T cell-dependent humoral immune response. J Exp Med (1996) 183(3):979-89. doi:10.1084/jem.183.3.979

194. Walker LS, Gulbranson-Judge A, Flynn S, Brocker T, Lane PJ. Co-stimulation and selection for T-cell help for germinal centres: the role of CD28 and OX40. Immunol Today (2000) 21(7):333-7. doi:10.1016/S0167-5699(00) 01636-4

195. Akiba H, Takeda K, Kojima Y, Usui Y, Harada N, Yamazaki T, et al. The role of ICOS in the CXCR5+ follicular B helper T cell maintenance in vivo. J Immunol (2005) 175(4):2340-8. doi:10.4049/jimmunol.175. 4.2340

196. Crotty S, Kersh EN, Cannons J, Schwartzberg PL, Ahmed R. SAP is required for generating long-term humoral immunity. Nature (2003) 421(6920):282-7. doi:10.1038/nature01318

197. Qi H, Cannons JL, Klauschen F, Schwartzberg PL, Germain RN. SAPcontrolled T-B cell interactions underlie germinal centre formation. Nature (2008) 455(7214):764-9. doi:10.1038/nature07345

198. Cannons JL, Qi H, Lu KT, Dutta M, Gomez-Rodriguez J, Cheng J, et al. Optimal germinal center responses require a multistage $\mathrm{T}$ cell:B cell adhesion process involving integrins, SLAM-associated protein, and CD84. Immunity (2010) 32(2):253-65. doi:10.1016/j.immuni.2010.01.010

199. Kageyama R, Cannons JL, Zhao F, Yusuf I, Lao C, Locci M, et al. The receptor Ly108 functions as a SAP adaptor-dependent on-off switch for T cell help to B cells and NKT cell development. Immunity (2012) 36(6):986-1002. doi:10.1016/j.immuni.2012.05.016 
200. Liu YJ, Joshua DE, Williams GT, Smith CA, Gordon J, MacLennan IC. Mechanism of antigen-driven selection in germinal centres. Nature (1989) 342(6252):929-31. doi:10.1038/342929a0

201. Walker LS, Gulbranson-Judge A, Flynn S, Brocker T, Raykundalia C, Goodall $\mathrm{M}$, et al. Compromised OX40 function in CD28-deficient mice is linked with failure to develop CXC chemokine receptor 5-positive CD4 cells and germinal centers. J Exp Med (1999) 190(8):1115-22. doi:10.1084/ jem.190.8.1115

202. Suan D, Nguyen A, Moran I, Bourne K, Hermes JR, Arshi M, et al. T follicular helper cells have distinct modes of migration and molecular signatures in naive and memory immune responses. Immunity (2015) 42(4):704-18. doi:10.1016/j.immuni.2015.03.002

203. Shulman Z, Gitlin AD, Targ S, Jankovic M, Pasqual G, Nussenzweig MC, et al. T follicular helper cell dynamics in germinal centers. Science (2013) 341(6146):673-7. doi:10.1126/science.1241680

204. Shulman Z, Gitlin AD, Weinstein JS, Lainez B, Esplugues E, Flavell RA, et al. Dynamic signaling by $\mathrm{T}$ follicular helper cells during germinal center B cell selection. Science (2014) 345(6200):1058-62. doi:10.1126/science. 1257861

205. Xu H, Li X, Liu D, Li J, Zhang X, Chen X, et al. Follicular T-helper cell recruitment governed by bystander B cells and ICOS-driven motility. Nature (2013) 496(7446):523-7. doi:10.1038/nature12058

206. Batista FD, Neuberger MS. B cells extract and present immobilized antigen: implications for affinity discrimination. EMBO J (2000) 19(4):513-20. doi:10.1093/emboj/19.4.513

207. Batista FD, Iber D, Neuberger MS. B cells acquire antigen from target cells after synapse formation. Nature (2001) 411(6836):489-94. doi:10.1038/ 35078099

208. Suzuki K, Grigorova I, Phan TG, Kelly LM, Cyster JG. Visualizing B cell capture of cognate antigen from follicular dendritic cells. J Exp Med (2009) 206(7):1485-93. doi:10.1084/jem.20090209

209. Zotos D, Coquet JM, Zhang Y, Light A, D’Costa K, Kallies A, et al. IL-21 regulates germinal center $\mathrm{B}$ cell differentiation and proliferation through a B cell-intrinsic mechanism. J Exp Med (2010) 207(2):365-78. doi:10.1084/ jem.20091777

210. Goenka R, Matthews AH, Zhang B, O’Neill PJ, Scholz JL, Migone TS, et al. Local BLyS production by $\mathrm{T}$ follicular cells mediates retention of high affinity B cells during affinity maturation. J Exp Med (2014) 211(1):45-56. doi:10.1084/jem.20130505

211. Fazilleau N, McHeyzer-Williams LJ, Rosen H, McHeyzer-Williams MG. The function of follicular helper $\mathrm{T}$ cells is regulated by the strength of $\mathrm{T}$ cell antigen receptor binding. Nat Immunol (2009) 10(4):375-84. doi:10.1038/ ni.1704

212. Knowlden ZA, Sant AJ. CD4 T cell epitope specificity determines follicular versus non-follicular helper differentiation in the polyclonal response to influenza infection or vaccination. Sci Rep (2016) 6:28287. doi:10.1038/ srep28287

213. Taylor JJ, Pape KA, Steach HR, Jenkins MK. Humoral immunity. Apoptosis and antigen affinity limit effector cell differentiation of a single naive B cell. Science (2015) 347(6223):784-7. doi:10.1126/science.aaa1342

214. Angelin-Duclos C, Cattoretti G, Lin KI, Calame K. Commitment of B lymphocytes to a plasma cell fate is associated with Blimp-1 expression in vivo. J Immunol (2000) 165(10):5462-71. doi:10.4049/jimmunol.165. 10.5462

215. Fooksman DR, Schwickert TA, Victora GD, Dustin ML, Nussenzweig MC, Skokos D. Development and migration of plasma cells in the mouse lymph node. Immunity (2010) 33(1):118-27. doi:10.1016/j.immuni.2010. 06.015

216. Phan TG, Paus D, Chan TD, Turner ML, Nutt SL, Basten A, et al. High affinity germinal center B cells are actively selected into the plasma cell compartment. J Exp Med (2006) 203(11):2419-24. doi:10.1084/jem. 20061254

217. Smith KG, Light A, Nossal GJ, Tarlinton DM. The extent of affinity maturation differs between the memory and antibody-forming cell compartments in the primary immune response. EMBO J (1997) 16(11):2996-3006. doi:10.1093/emboj/16.11.2996

218. Weisel FJ, Zuccarino-Catania GV, Chikina M, Shlomchik MJ. A temporal switch in the germinal center determines differential output of memory B and plasma cells. Immunity (2016) 44(1):116-30. doi:10.1016/j.immuni. 2015.12.004

219. Gitlin AD, von Boehmer L, Gazumyan A, Shulman Z, Oliveira TY, Nussenzweig MC. Independent roles of switching and hypermutation in the development and persistence of B lymphocyte memory. Immunity (2016) 44(4):769-81. doi:10.1016/j.immuni.2016.01.011

220. Shih TA, Roederer M, Nussenzweig MC. Role of antigen receptor affinity in T cell-independent antibody responses in vivo. Nat Immunol (2002) 3(4):399-406. doi:10.1038/ni776

221. Sciammas R, Shaffer AL, Schatz JH, Zhao H, Staudt LM, Singh H. Graded expression of interferon regulatory factor- 4 coordinates isotype switching with plasma cell differentiation. Immunity (2006) 25(2):225-36. doi:10.1016/j. immuni.2006.07.009

222. Erickson LD, Durell BG, Vogel LA, O'Connor BP, Cascalho M, Yasui T, et al. Short-circuiting long-lived humoral immunity by the heightened engagement of CD40. JClin Invest (2002) 109(5):613-20. doi:10.1172/ JCI0214110

223. Krautler NJ, Suan D, Butt D, Bourne K, Hermes JR, Chan TD, et al. Differentiation of germinal center $\mathrm{B}$ cells into plasma cells is initiated by high-affinity antigen and completed by Tfh cells. J Exp Med (2017) 214(5):1259-67. doi:10.1084/jem.20161533

224. Dogan I, Bertocci B, Vilmont V, Delbos F, Megret J, Storck S, et al. Multiple layers of B cell memory with different effector functions. Nat Immunol (2009) 10(12):1292-9. doi:10.1038/ni.1814

225. Taylor JJ, Pape KA, Jenkins MK. A germinal center-independent pathway generates unswitched memory B cells early in the primary response. J Exp Med (2012) 209(3):597-606. doi:10.1084/jem.20111696

226. Pape KA, Taylor JJ, Maul RW, Gearhart PJ, Jenkins MK. Different B cell populations mediate early and late memory during an endogenous immune response. Science (2011) 331(6021):1203-7. doi:10.1126/science. 1201730

227. Shinnakasu R, Inoue T, Kometani K, Moriyama S, Adachi Y, Nakayama M, et al. Regulated selection of germinal-center cells into the memory B cell compartment. Nat Immunol (2016) 17(7):861-9. doi:10.1038/ni.3460

228. Vinuesa CG, Sanz I, Cook MC. Dysregulation of germinal centres in autoimmune disease. Nat Rev Immunol (2009) 9(12):845-57. doi:10.1038/ nri2637

229. Detanico T, St Clair JB, Aviszus K, Kirchenbaum G, Guo W, Wysocki LJ. Somatic mutagenesis in autoimmunity. Autoimmunity (2013) 46(2):102-14. doi:10.3109/08916934.2012.757597

230. Woods M, Zou YR, Davidson A. Defects in germinal center selection in SLE. Front Immunol (2015) 6:425. doi:10.3389/fimmu.2015.00425

231. Martinet L, Garrido I, Filleron T, Le Guellec S, Bellard E, Fournie JJ, et al. Human solid tumors contain high endothelial venules: association with T- and B-lymphocyte infiltration and favorable prognosis in breast cancer. Cancer Res (2011) 71(17):5678-87. doi:10.1158/0008-5472.CAN11-0431

232. Cipponi A, Mercier M, Seremet T, Baurain JF, Theate I, van den Oord J, et al. Neogenesis of lymphoid structures and antibody responses occur in human melanoma metastases. Cancer Res (2012) 72(16):3997-4007. doi:10.1158/0008-5472.CAN-12-1377

233. Coppola D, Nebozhyn M, Khalil F, Dai H, Yeatman T, Loboda A, et al. Unique ectopic lymph node-like structures present in human primary colorectal carcinoma are identified by immune gene array profiling. Am J Pathol (2011) 179(1):37-45. doi:10.1016/j.ajpath.2011.03.007

234. de Chaisemartin L, Goc J, Damotte D, Validire P, Magdeleinat P, Alifano M, et al. Characterization of chemokines and adhesion molecules associated with $\mathrm{T}$ cell presence in tertiary lymphoid structures in human lung cancer. Cancer Res (2011) 71(20):6391-9. doi:10.1158/0008-5472.CAN11-0952

235. Chang PP, Barral P, Fitch J, Pratama A, Ma CS, Kallies A, et al. Identification of Bcl-6-dependent follicular helper NKT cells that provide cognate help for B cell responses. Nat Immunol (2012) 13(1):35-43. doi:10.1038/ ni. 2166

236. King IL, Fortier A, Tighe M, Dibble J, Watts GF, Veerapen N, et al. Invariant natural killer $\mathrm{T}$ cells direct $\mathrm{B}$ cell responses to cognate lipid antigen in an IL-21-dependent manner. Nat Immunol (2012) 13(1):44-50. doi:10.1038/ ni. 2172 
237. Liarski VM, Kaverina N, Chang A, Brandt D, Yanez D, Talasnik L, et al. Cell distance mapping identifies functional $\mathrm{T}$ follicular helper cells in inflamed human renal tissue. Sci Transl Med (2014) 6(230):230ra46. doi:10.1126/scitranslmed.3008146

238. Ise W, Kohyama M, Schraml BU, Zhang T, Schwer B, Basu U, et al. The transcription factor BATF controls the global regulators of class-switch recombination in both B cells and T cells. Nat Immunol (2011) 12(6):536-43. doi:10.1038/ni.2037

239. King C. New insights into the differentiation and function of $\mathrm{T}$ follicular helper cells. Nat Rev Immunol (2009) 9(11):757-66. doi:10.1038/nri2644

240. Linterman MA, Beaton L, Yu D, Ramiscal RR, Srivastava M, Hogan JJ, et al. IL-21 acts directly on B cells to regulate Bcl-6 expression and germinal center responses. J Exp Med (2010) 207(2):353-63. doi:10.1084/jem. 20091738

241. Nacionales DC, Kelly KM, Lee PY, Zhuang H, Li Y, Weinstein JS, et al. Type I interferon production by tertiary lymphoid tissue developing in response to 2,6,10,14-tetramethyl-pentadecane (pristane). Am JPathol (2006) 168(4):1227-40. doi:10.2353/ajpath.2006.050125

242. Schroder AE, Greiner A, Seyfert C, Berek C. Differentiation of B cells in the nonlymphoid tissue of the synovial membrane of patients with rheumatoid arthritis. Proc Natl Acad Sci U S A (1996) 93(1):221-5. doi:10.1073/ pnas.93.1.221

243. Kosco-Vilbois MH. Are follicular dendritic cells really good for nothing? Nat Rev Immunol (2003) 3(9):764-9. doi:10.1038/nri1179

244. Burton GF, Conrad DH, Szakal AK, Tew JG. Follicular dendritic cells and B cell costimulation. J Immunol (1993) 150(1):31-8.

245. Heesters BA, Myers RC, Carroll MC. Follicular dendritic cells: dynamic antigen libraries. Nat Rev Immunol (2014) 14(7):495-504. doi:10.1038/ nri3689

246. Aguzzi A, Kranich J, Krautler NJ. Follicular dendritic cells: origin, phenotype, and function in health and disease. Trends Immunol (2014) 35(3): 105-13. doi:10.1016/j.it.2013.11.001

247. Koopman G, Keehnen RM, Lindhout E, Newman W, Shimizu Y, van Seventer GA, et al. Adhesion through the LFA-1 (CD11a/CD18)-ICAM-1 (CD54) and the VLA-4 (CD49d)-VCAM-1 (CD106) pathways prevents apoptosis of germinal center B cells. J Immunol (1994) 152(8):3760-7.

248. Chhabra M, Conlon TM, Saeb-Parsy K, Pettigrew GJ. BAFF and associated TNF superfamily members in renal transplantation: an end to BLySful ignorance. Transplantation (2013) 96(10):853-9. doi:10.1097/TP. 0b013e3182997d34

249. Thaunat O, Patey N, Gautreau C, Lechaton S, Fremeaux-Bacchi V, Dieu-Nosjean MC, et al. B cell survival in intragraft tertiary lymphoid organs after rituximab therapy. Transplantation (2008) 85(11):1648-53. doi:10.1097/TP.0b013e3181735723

250. Mackay F, Figgett WA, Saulep D, Lepage M, Hibbs ML. B-cell stage and context-dependent requirements for survival signals from BAFF and the B-cell receptor. Immunol Rev (2010) 237(1):205-25. doi:10.1111/j.1600065X.2010.00944.x

251. Xu H, He X, Sun J, Shi D, Zhu Y, Zhang X. The expression of B-cell activating factor belonging to tumor necrosis factor superfamily (BAFF) significantly correlated with C4D in kidney allograft rejection. Transplant Proc (2009) 41(1):112-6. doi:10.1016/j.transproceed.2008.10.037

252. Doreau A, Belot A, Bastid J, Riche B, Trescol-Biemont MC, Ranchin B, et al. Interleukin 17 acts in synergy with B cell-activating factor to influence B cell biology and the pathophysiology of systemic lupus erythematosus. Nat Immunol (2009) 10(7):778-85. doi:10.1038/ni.1741

253. Ueno H. T follicular helper cells in human autoimmunity. Curr Opin Immunol (2016) 43:24-31. doi:10.1016/j.coi.2016.08.003

254. Craft JE. Follicular helper T cells in immunity and systemic autoimmunity. Nat Rev Rheumatol (2012) 8(6):337-47. doi:10.1038/nrrheum.2012.58

255. Linterman MA, Rigby RJ, Wong RK, Yu D, Brink R, Cannons JL, et al. Follicular helper T cells are required for systemic autoimmunity. J Exp Med (2009) 206(3):561-76. doi:10.1084/jem.20081886

256. Vinuesa CG, Cook MC, Angelucci C, Athanasopoulos V, Rui L, Hill KM, et al. A RING-type ubiquitin ligase family member required to repress follicular helper T cells and autoimmunity. Nature (2005) 435(7041):452-8. doi:10.1038/nature03555

257. Wing K, Onishi Y, Prieto-Martin P, Yamaguchi T, Miyara M, Fehervari Z, et al. CTLA-4 control over Foxp3+ regulatory T cell function. Science (2008) 322(5899):271-5. doi:10.1126/science.1160062
258. Kim HJ, Verbinnen B, Tang X, Lu L, Cantor H. Inhibition of follicular T-helper cells by CD8(+) regulatory $\mathrm{T}$ cells is essential for self tolerance. Nature (2010) 467(7313):328-32. doi:10.1038/nature09370

259. Sage PT, Sharpe AH. T follicular regulatory cells. Immunol Rev (2016) 271(1):246-59. doi:10.1111/imr.12411

260. Chung Y, Tanaka S, Chu F, Nurieva RI, Martinez GJ, Rawal S, et al. Follicular regulatory T cells expressing Foxp3 and Bcl-6 suppress germinal center reactions. Nat Med (2011) 17(8):983-8. doi:10.1038/nm.2426

261. Linterman MA, Pierson W, Lee SK, Kallies A, Kawamoto S, Rayner TF, et al. Foxp3+ follicular regulatory $\mathrm{T}$ cells control the germinal center response. Nat Med (2011) 17(8):975-82. doi:10.1038/nm.2425

262. Wollenberg I, Agua-Doce A, Hernandez A, Almeida C, Oliveira VG, Faro J, et al. Regulation of the germinal center reaction by Foxp3+ follicular regulatory T cells. J Immunol (2011) 187(9):4553-60. doi:10.4049/ jimmunol.1101328

263. Aloulou M, Carr EJ, Gador M, Bignon A, Liblau RS, Fazilleau N, et al. Follicular regulatory $\mathrm{T}$ cells can be specific for the immunizing antigen and derive from naive T cells. Nat Commun (2016) 7:10579. doi:10.1038/ ncomms 10579

264. Maceiras AR, Almeida SCP, Mariotti-Ferrandiz E, Chaara W, Jebbawi F, Six A, et al. $\mathrm{T}$ follicular helper and $\mathrm{T}$ follicular regulatory cells have different TCR specificity. Nat Commun (2017) 8:15067. doi:10.1038/ ncomms 15067

265. Vanderleyden I, Linterman MA, Smith KG. Regulatory T cells and control of the germinal centre response. Arthritis Res Ther (2014) 16(5):471. doi:10.1186/s13075-014-0471-7

266. Schwickert TA, Alabyev B, Manser T, Nussenzweig MC. Germinal center reutilization by newly activated B cells. J Exp Med (2009) 206(13):2907-14. doi:10.1084/jem.20091225

267. Schwickert TA, Lindquist RL, Shakhar G, Livshits G, Skokos D, Kosco-Vilbois $\mathrm{MH}$, et al. In vivo imaging of germinal centres reveals a dynamic open structure. Nature (2007) 446(7131):83-7. doi:10.1038/ nature 05573

268. Li Y, Takahashi Y, Fujii S, Zhou Y, Hong R, Suzuki A, et al. EAF2 mediates germinal centre B-cell apoptosis to suppress excessive immune responses and prevent autoimmunity. Nat Commun (2016) 7:10836. doi:10.1038/ ncomms 10836

269. ChristensenSR,ShupeJ,Nickerson K,KashgarianM,FlavellRA,ShlomchikMJ Toll-like receptor 7 and TLR9 dictate autoantibody specificity and have opposing inflammatory and regulatory roles in a murine model of lupus. Immunity (2006) 25(3):417-28. doi:10.1016/j.immuni.2006. 07.013

270. Jackson SW, Scharping NE, Kolhatkar NS, Khim S, Schwartz MA, Li QZ, et al. Opposing impact of B cell-intrinsic TLR7 and TLR9 signals on autoantibody repertoire and systemic inflammation. J Immunol (2014) 192(10): 4525-32. doi:10.4049/jimmunol.1400098

271. Nimmerjahn F, Ravetch JV. Fcgamma receptors as regulators of immune responses. Nat Rev Immunol (2008) 8(1):34-47. doi:10.1038/ nri2206

272. Smith KG, Clatworthy MR. FcgammaRIIB in autoimmunity and infection: evolutionary and therapeutic implications. Nat Rev Immunol (2010) 10(5): 328-43. doi:10.1038/nri2762

273. Espeli M, Clatworthy MR, Bokers S, Lawlor KE, Cutler AJ, Kontgen F, et al. Analysis of a wild mouse promoter variant reveals a novel role for FcgammaRIIb in the control of the germinal center and autoimmunity. J Exp Med (2012) 209(12):2307-19. doi:10.1084/jem.20121752

274. Kaneko Y, Nimmerjahn F, Ravetch JV. Anti-inflammatory activity of immunoglobulin G resulting from Fc sialylation. Science (2006) 313(5787): 670-3. doi:10.1126/science.1129594

275. El Shikh ME, Pitzalis C. Follicular dendritic cells in health and disease. Front Immunol (2012) 3:292. doi:10.3389/fimmu.2012.00292

276. Das A, Heesters BA, Bialas A, O’Flynn J, Rifkin IR, Ochando J, et al. Follicular dendritic cell activation by TLR ligands promotes autoreactive B cell responses. Immunity (2017) 46(1):106-19. doi:10.1016/j.immuni.2016. 12.014

277. Rahman ZS. Impaired clearance of apoptotic cells in germinal centers: implications for loss of B cell tolerance and induction of autoimmunity. Immunol Res (2011) 51(2-3):125-33. doi:10.1007/s12026-011-8248-4

278. Hanayama R, Tanaka M, Miyasaka K, Aozasa K, Koike M, Uchiyama Y, et al. Autoimmune disease and impaired uptake of apoptotic cells in MFG- 
E8-deficient mice. Science (2004) 304(5674):1147-50. doi:10.1126/science. 1094359

279. Win TS, Rehakova S, Negus MC, Saeb-Parsy K, Goddard M, Conlon TM, et al. Donor CD4 T cells contribute to cardiac allograft vasculopathy by providing help for autoantibody production. Circ Heart Fail (2009) 2(4):361-9. doi:10.1161/CIRCHEARTFAILURE.108. 827139

280. Harper IG, Ali JM, Harper SJ, Wlodek E, Alsughayyir J, Negus MC, et al. Augmentation of recipient adaptive alloimmunity by donor passenger lymphocytes within the transplant. Cell Rep (2016) 15(6):1214-27. doi:10.1016/j.celrep.2016.04.009

281. Qureshi MS, Motallebzadeh R, Chhabra M, Negus M, Rehakova S, Bolton E, et al. Germinal centre autoimmunity mediates progression of allograft vasculopathy, with essential help provided by $\mathrm{T}$ follicular cells. American Transplant Congress. Philadelphia (2015).
282. Suciu-Foca N, Harris PE, Cortesini R. Intramolecular and intermolecular spreading during the course of organ allograft rejection. Immunol Rev (1998) 164:241-6. doi:10.1111/j.1600-065X.1998.tb01224.x

Conflict of Interest Statement: The authors declare that the research was conducted in the absence of any commercial or financial relationships that could be construed as a potential conflict of interest.

Copyright $\odot 2017$ Alsughayyir, Pettigrew and Motallebzadeh. This is an open-access article distributed under the terms of the Creative Commons Attribution License (CC BY). The use, distribution or reproduction in other forums is permitted, provided the original author(s) or licensor are credited and that the original publication in this journal is cited, in accordance with accepted academic practice. No use, distribution or reproduction is permitted which does not comply with these terms. 